\title{
INTERNATIONAL ANTITRUST - WHAT LAW IN ACTION?
}

\author{
Damjan Kukovec ${ }^{\prime}$
}

\section{INTRODUCTION}

Prohibition of the General Electric/Honeywell merger by the European Commission $^{2}$ and the difference of opinion between the European Commission and the Federal Trade Commission (FTC) over the Boeing/McDonnell Douglas $(\mathrm{MCD})^{3}$ merger shook transatlantic relations. Indeed, these different decisions almost escalated into a trade war. ${ }^{4}$ Disputes arising out of antitrust enforcement, problems caused by the polycentric world of decision-makers on the world stage, and questions of market access sparked an intense debate on the international antitrust regime, as well as on the world order in general. The most frequently discussed possible solutions to disputed issues in international antitrust law are the World Trade Organization (WTO), the Organization for Economic Co-operation and Development (OECD), an independent antitrust

1. LL.M. (Harvard Law School, 2002), dipl.iur. (University of Ljubljana, 2001). Many thanks to Prof. William P. Alford, Prof. David W. Kennedy, Prof. Morton J. Horrowitz, Oren Bracha, and Prof. Thomas E. Kauper for their advice. I also owe special thanks to Prof. Boštjan M. Zupančič, Justice of the European Court of Human Rights, for his lectures on jurisprudence at the University of Ljubljana. An earlier version of this Article was written in partial fulfillment of the LL.M. criteria at Harvard Law School. This Article is dedicated to the memory of my grandmother, Amanda Mahkovec.

2. Case COMP/M.2220, General Electric/Honeywell v. Commission (2001), http://europa.eu.int/eur-lex/pri/en/oj/dat/2004/1_048/1_04820040218en00010085.pdf (last visited Nov. 23, 2004), appeal docketed, Case T-210/01, Action brought on 12 September 2001 by the General Electric Company against the Commission of the European Communities, http://europa.eu.int/eur-lex/pri/en/oj/dat/2001/c_331/c_33120011124en00240025.pdf [hereinafter $G E /$ Honeywell].

3. Decision 97/816/EC, Commission Decision of July 30, 1997 declaring a concentration compatible with the common market and the functioning of the EEA Agreement, 1997 O.J. (L 336) 16 [hereinafter Boeing/MCD] (approving the Boeing/McDonnell Douglas merger under conditions); Joint Statement by Chairman Robert Pitofsky \& Commissioners Janet D. Steiger, Roscoe B. Starek III \& Christine A. Varney, Federal Trade Commission, In the Matter of the Boeing Company/McDonnell Douglas Corporation, File No. 971-0051 (July 1997), http://www.ftc.gov/lopa/1997/07/boeingsta.htm (approving the Boeing/McDonnell Douglas merger with an unprecedented statement) [hereinafter In re Boeing].

4. See, e.g., Merit E. Janow, Transatlantic Cooperation in Competition Policy, in ANTITRust Goes Global: What Future for Transatlantic CoOperation? 44 (Simon J. Evenett et al. eds., 2000); Sarah Stevens, The Increased Aggression of the EC Commission in Extraterritorial Enforcement of the Merger Regulation and Its Impact on Transatlantic Cooperation in Antitrust, 15 SYRACUSE J. INT'L L. \& COM. 263, 276 (2002) ("The Commission's subsequent decision to block the [GE] merger resulted in political pressure on Bush to retaliate with trade sanctions, raising the spectre of an antitrust-inspired trade war."). 
organization, bilateral cooperation, and positive comity. ${ }^{5}$ These issues arose parallel to the debate on the "legalization" of international law and a shift away from power politics.

This Article attempts to establish what the law in action ${ }^{8}$ is, and examines the consequences of both the current regime and some of the proposed regimes, including their distributive consequences. Furthermore, it demonstrates that some of the arguments and proposals in international antitrust discourse are "paper rules," or proposals without any real effect in the international arena, and that some proposals may have hidden undesired effects. This Article also attempts to show the fallacy of the dichotomy between reason and force ${ }^{10}$ in international law and international relations and the fallacy of the liberal model.

Part II examines the concept of the extraterritorial effect and how it compares to the principle of territoriality. It also attempts to explain why disputes in international merger review occur. It demonstrates very limited applicability of liberal international relations theory to international antitrust

5. See generally Janow, supra note 4; Eleanor M. Fox, Competition Law and the Millenium Round, 2 J. INT'L ECON. L. 665 (1999); Daniel K. Tarullo, Norms and Institutions in Global Competition Policy, 94 AM. J. INT'L. L. 491 (2000); Andrew T. Guzman, Antitrust and International Regulatory Federalism, 76 N.Y.U. L. REV. 1142 (2001).

6. See, e.g., Anne-Marie Slaughter, International Law and International Relations, in 285 RECUEII DES CouRs: COLLCTED COURSES OF THE HAGUE ACADEMY OF INTERNATIONAL LAw 9, 204-11 (Académie de Droit International ed., 2000).

7. Anne-Marie Slaughter, Interdisciplinary Approaches to International Economic Law: Liberal International Relations Theory and International Economic Law, 10 AM. U. J. INT'L L. \& POL'Y 717, 730-31 (1995) [hereinafter Slaughter, Liberal International Relations Theory and International Economic Law] (arguing that the focus on interests rather than on power in turn shifts attention away from territory, or other sources of state power, to the modes and accuracy of representation of social interests); see also Anne-Marie Slaughter, A Global Community of Courts, 44 HARV. INT'L. L.J. 191, 219 (2003) [hereinafter Slaughter, A Global Community of Courts] (arguing that relations between judges in a global community of courts are shaped by the ultimate need, in a world of law, to rely on reason rather than force).

8. See Oliver Holmes, The Path of the Law, 10 HARv. L. Rev. 457, 459-61 (1897):

If you want to know the law and nothing else, you must look at it as a bad man, who cares only about the material consequences which such knowledge enables him to predict. ... What constitutes the law? You will find some text writers telling you that it is something different from what is decided by the courts of Massachusetts or England, that it is a system of reason, that it is a deduction from principles of ethics or admitted axioms or what not, which may, or may not coincide with the decisions. [The bad man] does not care two straws for the axioms or deductions, but ... he does want to know what the Massachusetts or English courts are likely to do in fact.... The prophecies of what the courts will do in fact, and nothing more pretentious, are what I mean by the law.

Id.

9. See Karl N. Llewellyn, Some Realism About Realism-Responding to Dean Pound, 44 HARV. L. REV. 1222, 1237 (1931).

10. See, e.g., Slaughter, A Global Community of Courts, supra note 7. For the opinion that reason may not be pluralist, and thus problematic, see Damjan Kukovec, Cultural Relativism, International Criminal Courts and International Relations (May 2002) (unpublished manuscript, on file with author) and Damjan Kukovec, Changing Conceptions of Sovereignty (Dec. 30, 2000) (unpublished manuscript, on file with Harvard Law School and author). 
law. Does the concept of positive comity work? How is the Third World caught in the middle of transatlantic disputes? Should every country be exercising extraterritorial jurisdiction? Part III examines the question of national bias and international commercial arbitration, and problems of adjudication in international law. It is argued that the non-discrimination principle cannot be effective in international antitrust. Part IV deals with the relationship between trade and non-trade issues and the general problem of the proliferation of decision-makers in international law.

\section{EXTRATERRITORIAL EFFECT}

\section{A. Problems With the Concept of Extraterritorial Effect}

According to Fiebig, ${ }^{11}$ there now seems to be a consensus that an effect on competition within a specific territory may constitute a legitimate nexus upon which to base jurisdiction over activities occurring outside of that territory. Nevertheless, extraterritorial effect can prove to be a problematic concept.

The United States was the first to use the extraterritorial effect in antitrust law. ${ }^{12}$ However, as "an interference with the authority of another sovereign, which the other state concerned might justly resent," Justice Holmes claimed that extraterritoriality was "contrary to the comity of nations." 13 Slaughter, on the other hand, argues that the wording of American Banana Co. v. United Fruit $\mathrm{Co}^{14}$ reflected a world of strictly-bound national territories in which legislative power was co-extensive with physical power over a defined territory. Extraterritorial effect is a negation of the realist ${ }^{15}$ account of "[s]tates as billiard balls: opaque, hard, clearly defined spheres interacting through collision with one another."16 The principle of territorial protection and "the rule of reason remain closely tied to territory, and with it, to lurking notions of physical power." 17 Slaughter argues that it is therefore "important to push beyond a posited or even asserted concept of state interest to examine the actual interests

11. Andre Fiebig, A Role for the WTO in International Merger Control, 20 Nw. J. INT'LL. \& Bus. 233, 237 (2000).

12. Youri Devuyst, Transatlantic Competition Relations, in TransatLantic GoverNaNCE IN THE Global ECONOMY 127, 130-31 (Mark A. Pollack \& Gregory C. Shaffer eds., 2001).

13. Am. Banana Co. v. United Fruit Co., 213 U.S. 347, 356 (1909).

14. Id.

15. Throughout this Article, the term "realist" refers to the paradigm in international relations theory which claims that power determines the outcomes of state interactions, that international law is epiphenomenal, and that states are primary actors in the international system. The term "legal realist" refers to the jurisprudential school of reform jurisprudence. See, e.g., AMERICAN LeGal REALISM 3-8 (William W. Fisher III et al. eds., 1993).

16. Slaughter, supra note 6 , at 34 .

17. Slaughter, Liberal International Relations Theory and International Economic Law, supra note 7 , at 736 . 
of individuals and groups as represented by the state" and to use the principle of extraterritoriality. ${ }^{18}$

The theory of antitrust has traditionally dealt with disputes between a firm engaging in an anticompetitive practice, such as a cartel, ${ }^{19}$ and the public interest, that is to say consumers who are represented by antitrust regulators. In these cases, agencies are often forced to cooperate with each other if they are to prosecute such practices effectively, particularly where the acts involved transcend national borders. ${ }^{20}$ The authorities therefore have a common opponent, the corporation, which Fox vividly described as the "common evil.",21 This is where the original conflict between the "public interest" and the corporation is preserved.

Under the current world antitrust regime, merger disputes are different. As a result of the extraterritorial effect, there are two or possibly more horizontal-level decision-makers who decide whether the transaction, such as the merger between General Electric (GE) and Honeywell or Boeing and MCD is compatible with antitrust laws. Thus, a veto right ${ }^{22}$ is established by which the most prohibitive enforcer prevails. ${ }^{23}$ A major foreign transaction can be prohibited, which foreign governments and interests resent, particularly if the same transaction was cleared at home. The issue in dispute with merger review is not previous or ongoing anticompetitive practice, but the decision of the regulator itself, ${ }^{24}$ which will or has already been taken within tight deadlines. The conflict here is not an administration-corporation conflict, but a conflict between governments representing the interests of their constituencies. Different decisions have almost sparked trade wars, and have been the cause of transatlantic disputes. The conflict between the regulator and the corporation escalates into a dispute between nations ${ }^{25}$ through the exercise of the veto right.

18. Id.

19. Joel I. Klein, Remarks to the Royal Institute of International Affairs, http://www.usdoj.gov/atr/public/speeches/jikspch.htm (Nov. 18, 1996) (noting that international cartel cases, in which competitors in various countries come together privately to fix prices or allocate territories worldwide, can have an impact on trade by taking enormous amounts of money out of the pockets of consumers around the world).

20. See Spencer Weber Waller, Anticartel Cooperation, in ANTTTRUST GoEs Global: What Future FOR Transatlantic CoOpERATION? 98, 98-99 (Simon J. Evenett et al. eds., 2000); Tarullo, supra note 5, at 491.

21. Eleanor M. Fox, Toward World Antitrust and Market Access, 91 AM J. INT'L. L. 1, n.2 (1997).

22. Simon J. Evenett et. al., Antitrust Policy in an Evolving Global Marketplace, in ANTtrRust Goes Global: What Future for Transatlantic CoOperation? 1, 17, 21-22 (Simon J. Evenett et al. eds., 2000).

23. Eleanor M. Fox, Global Problems In a World Of National Law, 34 NEw ENG. L. REV. 11, 12 (1999).

24. This was demonstrated by the outcry of politicians, the media, and eventually academia. See infra Part III. A.

25. See Thomas M. Franck, The Independence and Impartiality of International Judges, 83 AM. SOC'y INT'L L. Proc. 508, 520 (1989). 
Why are the United States and the European Union primarily exercising the extraterritorial effect, and why are antitust disputes only between them? First, the scale of economic cooperation between the two entities is unprecedented. ${ }^{26}$ Cross-border flows of goods create international policy externalities, which in turn create incentives for policy coordination. ${ }^{27}$ Second, and most importantly, these jurisdictions are both able to effectively enforce their decisions. ${ }^{28}$ A country's effectiveness in applying its antitrust laws extraterritorially depends on its ability to obtain jurisdiction over the defendants, and enforce any resulting judgment against the defendants' assets. In both of these areas, the United States and the European Union enjoy a distinct advantage by virtue of their size. ${ }^{29}$ A foreign defendant is likely to have more contacts with the United States or the European Union on which personal jurisdiction might be based, as well as more assets in the United States or the European Union against which a judgment might be enforced, than is the case with a smaller country. ${ }^{30}$

States, as agents of interests, outside the European Union and the United States, do not have the same veto right. Extraterritorial effect, as it is known today, creates only a limited number of effective decision-makers as the enforcement of such a decision rests on the economic power of the enforcer's jurisdiction. There was no dispute, no collision with other nations, no talk of "right" or "wrong" outside the discourse between the European Union and United States. Although, in both merger cases there was undoubtedly a conflict of interest between the merging firm and consumers in many countries around the world, as Boeing and GE sell far beyond the United States and European Union markets. ${ }^{31}$

This is true, both in countries that have adopted and have not adopted antitust rules. National and international society is permeated with conflicts of interests. $^{32}$ Thus, it follows that there are more silent conflicts of interests than

26. See, e.8., Janow, supra note 4, at 29-30.

27. Andrew Moravcsik, Preferences and Power in the European Community: A Liberal Intergovernmentalist Approach, 31 J. COMMON MARKET STUD. 473, 485 (1993).

28. See William S. Dodge, Antitrust and the Draft Hague Judgments, 32 J. L. POL'Y \& INT'L. Bus. 363, 364, 380-84 (2001).

29. Id.

30. Id.

31. For information on Boeing's deliveries in 1997, see Boeing Report, at http://active. boeing.com/commercial/orders/displaystandardreport.cfm?optReportType=Delivery\&cbo ReportMonth=12\&cboReportQuarter=\&optTimePeriod=Yearly\&cboReportYear=1997\& View ReportS=View+Report (last visited Nov. 15, 2004). For General Electric's activities, see GE's web page, at http://www.ge.com/en/ge/country.html (n.d.) (last visited Nov. 22, 2004).

32. See Friedrich NiETzSCHE, ON THE GENEALOGY OF MORALS 76 (Walter Kaufmann ed., Walter Kaufmann \& R. J. Hollingdale trans., Vintage Books 1989) (1887) ("[L]ife operates essentially, that is in its basic functions, through injury, assault, exploitation, destruction and simply cannot be thought of at all without this character."); Andrew Moravcsik, Taking Preferences Seriously: A Liberal Theory of International Politics, 54 INT'L. ORG. 513, 517 (1997) (arguing that "liberal theory rejects the utopian notion that an automatic harmony of 
there are actual disputes. ${ }^{33}$ This claim is nothing but a procedural extension of the position that ground rules of permission are just as important as ground rules of prohibition. ${ }^{34}$ Permitting ability of some and inability of the rest to exercise extraterritorial effect is as important as prohibiting the rest to exercise it.

Zupancii argues that within the framework of criminal procedure, conflict of interest and equality of power in a concrete case are the bases for legal disputes where there can be any talk of "right" or "wrong." 35 .The same is true, as will further be shown, for other fields, such as international antitrust. The concept of power under Zupancič's premise is most closely related to that of Deutsch, who argued that "to have power means not to have to give in, and to force the environment or the other person to do so."36 "Power in this narrow sense is the priority of output over intake, the ability to talk instead of listen ... the ability to afford not to learn." 37 This equality of power on the world stage is not necessarily realist power possessed by one of the conflicting parties in absolute terms. ${ }^{38}$ It is just as well the liberal "willingness of governments to mobilize and expend social resources for foreign policy purposes," or "strong preference for the issue at stake ....,"39 Only after equality of power in this sense has been established in a concrete "issue at stake" 40 can a real dispute in need of an equitable solution be discussed.

Not all regulators are equally powerful, which is why the only interests examined are those of individuals in powerful jurisdictions. ${ }^{41}$ Third World consumers and companies or those from comparatively small, developed countries have absolutely no power when a merger has negative effects on them and their respective societies. Thus, for example, the Zambian Competition Commission could not effectively prohibit the GE/Honeywell merger no matter

interests exists among individuals and groups in society; scarcity and differentiation introduce an inevitable measure of competition").

33. Two scenarios clearly show this. Either a person victimizes another person because there is no regulation of the activity of the victimizing person, or someone is not able to voice his say and interest, although the relationship is regulated. The end result is the same. Compare DunCAN KenNEDY, SEXY DRESSING ETC. 90-91 (1993).

34. Id.

35. See Bostuan M. ZuPančič, Prvine Pravne Kulture 199 (1995) (arguing that a legal dispute is artificially created in criminal procedure); BOSTJAN M. ZUPANČ́C, ODLOČBE IN RAZPRAVE 255 (1991).

36. Karl W. Deutsch, The Nerves of Government 111 (1966).

37. Id. Cf. Roberto M. Unger, KNOWLedge AND Polmics 64 (1975) ("Power is the capacity to command, to subordinate the will of others to one's own will.").

38. See Moravcsik, supra note 32, at 519 (explaining that realists and institutionalists assume that states "automatically maximize fixed, homogenious conceptions of security, sovereignty or wealth per se ....").

39. Id. at 524 (emphasis omitted).

40. Id.

41. See, e.g., Eleanor. M. Fox, International Antitrust and the Doha Dome, 43 VA. J. INT'L. L. 911 , 922, n.30 (2003) (citing cases which may have affected Mexico); see also Fox, supra note 23, at 12 ("[L]ess developed and developing countries lack the power to reach and discipline offshore actors that harm them."). 
how much they as well as possible competitors and consumers in its market wished to, regardless of their preferences and interests. ${ }^{42}$ On the other hand, any merger occurring in other parts of the world is subject to careful scrutiny by the two jurisdictions that are able to effectively exercise extraterritorial power. ${ }^{43}$

Antitrust discourse, therefore, remains primarily between the United States and the European Union: Is the judicialized system of the United States "right;" is the "dominance test" "right" or "wrong;" or is "the substantial lessening of competition test" "right?"44 Are the goals of competition law to promote market competition and efficiency, or should it strengthen the economic and social cohesion ? $^{45}$ Should the GE/Honeywell merger be cleared? Academic debate focuses almost exclusively on these two jurisdictions and the interactions between them. Technical assistance on antitrust law is offered to other countries by either the United States or the European Union. ${ }^{46}$

The debate within the International Competition Network also involves other countries, but seems to be in the shadow of "the biggest elephants" of world trade, ${ }^{47}$ and does not deal with concrete cases and disputes. ${ }^{48}$ Other

42. See also Dodge, supra note 28 , at $380-84$ (noting that "[a]lthough in the past and at present there may have been an effect by foreign companies and their anticompetitive actions on the consumers of small countries, they did not have the power to enforce it"). For the argument that liberal international relations theory is not applicable to international antitrust see infra Part II. A.

43. See, e.g., Case T-102/96, Gencor Ltd. v. Commission, 1999 E.C.R. 753 (2001). In the United States, thresholds for jurisdiction under Section 7 of the Clayton Act (15 U.S.C. $§ 1981$ (2003)) are lower than those under the European Merger Regulation. Cf. infra note 156. Nevertheless, individual countries of the European Union can also effectively prosecute a merger under their individual antitrust laws. Their respective economies are similarly much larger proportionally than those of the rest of the world, so that they could again effectively exercise the "effects doctrine" vis-à-vis the smaller jurisdictions.

44. See, e.g., Henry Huser \& Frederic Depoortere, Substantive Enforcement Standards in Horizontal Mergers Under the EC Merger Regulation, in ANTITRUST 44 (2002).

45. See, e.g., Yeo Jin Chun, The GE-Honeywell Merger Debacle: The Enforcement of Antitrust/Competition Laws Across the Atlantic Pond, 15 N.Y. INT'L L. REv. 61 (2002) (arguing that the former is the U.S. approach and the latter European).

46. Evenett et al., supra note 22, at 24.

47. Pascal Lamy, US-EU: The Biggest Trading Elephants in the Jungle-But Will They Behave?, Address before the Economic Strategy Institute (June 7, 2001), http://www.econstrat. org/publications/plamy.htm (last visited Nov. 19, 2004). The International Competition Network (ICN) was created with essential support from the two jurisdictions. The International Competition Network, History, http://www.internationalcompetitionnetwork.org/ history.html (n.d.) (last visited Nov. 27, 2004). Although contributions to projects are made from all members, none can match the expertise and resources of the European Commission, the Department of Justice, and the Federal Trade Commission. Id.

48. The ICN is project-driven. It will address antitrust enforcement and policy issues of common interest and formulate proposals for procedural and substantive convergence through a results-oriented agenda and structure. The ICN will generate recommendations on best practices and it will be left to the individual antitrust agencies to decide whether and how to implement them. Where the ICN reaches consensus on recommendations arising from the projects, it will be left to the individual antitrust agencies to decide whether and how to implement the recommendation. International Competition Network, Memorandum on the Establishment and 
states are simply not real participants in the discourse. Prior to the 1980 s, when the Commission did not enforce the extraterritorial principle, there were no disputes. Blocking statutes ${ }^{49}$ were a first echo of the inability to reciprocate extraterritorial effect. There was a conflict of interest, but there were no disputes like those that have arisen in the last decade, because only one jurisdiction was exercising the law of extraterritorial effect. The situation eventually resulted in the European Union's equivalent to the United States. ${ }^{50}$

Outcomes of merger investigations and their enforcement are reserved for the two powerful agents of group and individual interests, irrespective of the preferences of the others. Devuyst explains that "what really sets competition relations apart from trade policy is that the FTC, the Department of Justice, and the European Commission are all under a legal duty to act independently and on the basis of the law when assessing antitrust cases." 51 The decisions of the competition authorities are not made on the basis of a bargaining process, but according to law, ${ }^{52}$ and according to "reason rather than force." $" 53$ Law is an independent variable, and economic power is a fixed premise. Therefore, international antitrust issues are not subject to negotiation. Those who do not have the power to enforce law will not be able to protect their constituencies; rather, only the powerful ones will be able to do so.

Liberal theory holds that the outcome of state interactions is a function, at least in the first instance, not of relative power capabilities but of the configuration and intensity of state preferences. ${ }^{54}$ Liberal theory assumes that the pattern of interdependent state preferences imposes a binding constraint on state behavior, and thus, each state seeks to realize its distinctive preferences under varying constraints imposed by the preferences of other states. "What states want is the primary determinant of what they do." 55 Thus, variation in ends not means matters most. ${ }^{56}$ However, it sometimes is not just what states want and how much they want it, but also who makes the decision. The ultimate arbiters in competition cases are not presidents or prime ministers, but

Operation of the International Competition Network, at http://www.internationalcompetition network.org/mou.pdf (last visited Nov. 22, 2004).

49. Edward T. Swaine, The Local Law of Global Antitrust, 43 WM. \& MARY L. REV. 627, 644-45 (2001). Two years after Alcoa, the United States attempted to gather Canadian evidence in price fixing proceedings against U.S. and Canadian paper firms, which led to the adoption of blocking statutes designed to frustrate discovery by many U.S. trading partners. See Alcoa S.S. Co. Inc. v. M/V Nordic Regent, 645 F. 2d 147, 152 (2d Cir. 1980).

50. See Dodge, supra note 28 , at 381 ("[S]ince the 1980s, the European Union has begun to apply its competition law extraterritorially in ways that mirror the United States.").

51. Devuyst, supra note 12, at 150-51.

52. For the Antitrust Division's independence from undue influence by other federal agencies, see Thomas E. Kauper, Politics and the Justice Department: A View from the Trenches, 9 J.L. \& POL. 257, 258 (1993); see also Fox, supra note 21, at 18 (noting that a domestic antitrust agency is not always immune from statist pressures from above).

53. Slaughter, A Global Community of Courts, supra note 7, at 219.

54. Slaughter, Liberal International Relations Theory and International Economic Law, supra note 7 , at 728 .

55. Moravcsik, supra note 32 , at 521 .

56. Id. at 522 . 
rather the courts. ${ }^{57}$ Negotiations take place at the level of remedies, ${ }^{58}$ but not at the level of adjustments of the outcomes of merger reviews, according to other policies pursued by states such as the United States and the European Union. Liberal theory, on the other hand, applies to the strategic calculations of governments and national leaders. ${ }^{59}$ It is based on an assumption more consistent with basic theories of bargaining and negotiation than the assumptions underlying realism, as the willingness of states to expend resources or make concessions is itself primarily a function of preferences rather than capabilities. $^{60}$ Bargaining, and thus liberal international relations theory, are therefore applicable to international antitrust insofar as it is admissible to say that agency and court decisions ${ }^{61}$ in liberal states ${ }^{62}$ in disputes between liberal or non-liberal states ${ }^{63}$ are or can be influenced by national leaders. If they are

57. See Devuyst, supra note 12, at 151 ("The regulatory cooperation dynamics based on law ... is therefore what really characterizes antitrust cooperation in comparison with most other areas of transatlantic relations.").

58. See, e.g., id. at 144 (explaining how the deadlock in negotiations between Boeing and the European Commission was broken by Boeing through a last-minute concession).

59. Moravcsik, supra note 32, at 513, 520-23.

60. Id. at 523 .

61. Antitrust decisions both in the European Union and in the United States enter the court system. In the European Union, they enter through the Court of First Instance and European Court of Justice (ECJ). See EC TREATY art. 225. In the United States antitrust decisions enter through a federal court to the U.S. Supreme Court. See, e.g., MARK R. JoELSON, an International antitrust Primer a Guide to the Operation of United States, EUROPEAN UNION, AND OTHER Key CoMPETTTION LAWS IN THE GLOBAL ECONOMY 34-35 (2d ed. 2001). Devuyst explains that any Commission decision deviating from the principles of the ECJ is likely to be overturned. This leaves little margin for political bargaining. See Devuyst, supra note 12 , at 150 .

62. Anne-Marie Burley, Law Among Liberal States: Liberal Internationalism and the Act of State Doctrine, 92 Colum. L. REv. 1907, 1910 (1992):

Liberal states operate in a 'zone of law,' in which domestic courts regulate transnational relations under domestic law. Courts within this zone evaluate and apply the domestic law of foreign states in accordance with general pluralist principles of mutual respect and interest-balancing. Nonliberal states, by contrast, operate in a 'zone of politics,' in which domestic courts either play no role in the resolution of transnational disputes or allow themselves to be guided by the political branches.

Id. This is not to say that the courts of liberal states are not subject to a range of nonlegal influences, both political and personal. It is to claim, however, at least for the purposes of this hypothetical model, that the courts of liberal states operate in a sphere distinct from that of the political branches. The legislature may pass the laws, and the executive may decide when and to what extent to enforce them, but their actual interpretation and application in a particular case is for the courts alone.

63. For this distinction, see id. at 1960-61.

[L]iberal internationalist model ... predicts that the courts of liberal states will seek to safeguard their autonomy even at the cost of foregoing their normal adjudicatory function. They themselves can determine when the limits of that function, and by implication, the limits of law in the international realm, have been reached, and can voluntarily cede their place to the political branches. 
not so influenced, liberal international relations theory cannot be applied to international antitrust. ${ }^{64}$ If, on the other hand, the premise that courts are influenced by national leaders is adopted, Slaughter's model of a global community of independent courts ${ }^{65}$ in which "participating judges see each other not only as servants and representatives of a particular polity, but also as fellow professionals in an endeavor that transcends national borders, "66 where the "“end of justice,' the special province of judges," feeble grounds. If the middle ground is taken, that court decisions may sometimes be influenced by governments and sometimes not, both propositions are at best relative.

Disputes and disputes arising from litigation of underlying disputes ${ }^{68}$ are therefore not "themselves inevitable byproducts of a globalizing economy."69 Rather, they are determined by ground rules. ${ }^{70}$ If law is an independent variable, ${ }^{71}$ reality must to some extent be a dependent one. The concept of extraterritorial effect is not based on "lurking notions of power,"72 but on the conflict of individual and group interests represented by states. ${ }^{73}$ Yet law in action, and the distributive approach beginning with the group conflict and asking how it is affected by legal institutions, ${ }^{74}$ show us that the end result of the extraterritorial effect is strikingly similar to that of the principle of territoriality, favoring the interests of individuals and groups from powerful

Id. In cases involving nonliberal states, the tension between judicial autonomy and an inclination to allow the executive to dictate the result will continue.

64. Moravcsik, supra note 32 , at 518.

In the liberal conception of domestic politics, the state is not an actor but a representative institution constantly subject to capture and recapture, construction and reconstruction by coalitions of social actors. Representative institutions and practices constitute the critical 'transmission belt' by which the preferences and social power of individuals and groups are translated into state policy.

Id. Liberal international relations theory can therefore, if at all, be used for antitrust relations among "nonliberal" states, those whose executive and judiciary are not truly separated. That is, of course, when such a country acquires the ability to effectively enforce antitrust.

65. Slaughter, A Global Community of Courts, supra note 7, at 218-19.

66. Slaughter, Liberal International Relations Theory and International Economic Law, supra note 7, at 738 ("'[R]eliance on a foreign sovereign's claim of interest in a specific case may reflect nothing more than an individual litigant's ability to pressure the Foreign Office, a relatively costless benefit a government can provide to its citizens on a case by case basis.").

67. Slaughter, A Global Community of Courts, supra note 7, at 210.

68. See Franck, supra note 25.

69. Slaughter, A Global Community of Courts, supra note 7, at 218.

70. For the possibility of "revolutionary" changes in the distribution of income, wealth, power, and knowledge between social groups by changing ground rules, see KENNEDY, supra note 33 , at 84-85, 107.

71. Independent from power in realist terms. See infra note 83. On the dependence between facts and norms, see infra Part III. B.

72. Slaughter, Liberal International Relations Theory and International Economic Law, supra note 7 , at 736 .

73. Id. at 729-31.

74. Duncan Kennedy, A Critique of Adjudication: Fin De Siècle 66 (1997). 
jurisdictions. ${ }^{75}$ The "ground rules" ${ }^{76}$ remain similar although they are premised on supposedly completely divergent theories of "the way the world works." The principle of territoriality as opposed to the principle of extraterritoriality is therefore more closely tied to the notion of direct physical control than to that of physical power. ${ }^{78}$

Physical power is very much connected with economic power in the modern world, ${ }^{79}$ and economic power is a key factor in the effectiveness of extraterritorial effect. This argument against extraterritoriality is therefore not based on Holmes' Austinian ${ }^{80}$ objection that it infringes upon state sovereignty. It is rather based on the fact that the extraterritorial effect, which triggers duplication of decision-making and creates disputes when equally powerful interests collide, ${ }^{81}$ otherwise works more or less invisibly in favor of interests from powerful jurisdictions. Inability to exercise extraterritorial effect is by no means one of the most pressing problems of the developing world. But this shows how the "inevitable" 82 ground rules are tilted in favor of the two established ones.

As Thomas Franck proclaims, "we are finally in a "post-ontological era." "83 But he also emphasized the focus on how fair international law is. ${ }^{84}$ Law is an independent variable in the international arena, but the key question becomes how this law plays out, and specifically in international antitrust, who has the power to enforce their ex post facto logical explanation of their

75. See also infra Part II. C.

76. See KENNEDY, supra note 74 , at 74 .

77. Slaughter, Liberal International Relations Theory and International Economic Law, supra note 7 , at 719 .

78. Contra id. at 736.

79. Calls for a permanent membership of Japan, Germany, and Italy in the Security Council of the United Nations, which is a realist structure (see infra note 353), are not a coincidence. See, e.g., The Ministry of Foreign Affairs of Japan, Visit to Europe By Prime Minister Keizo Obuchi, at http://www.mofa.go.jp/region/europe/pmv9901/speech.html (January 18, 1999); see also Four Nations Launch UN Seat Bid, BBC NEwS, at, http://news.bbc.co.uk/ 1/hi/world/americas/3678736.stm (Sept. 22, 2004); Germany Slams Italy over UN Plan, BBC NEws, at http://news.bbc.co.uk/1/hi/world/europe/3689796.stm (Sept. 25, 2004).

80. For John Austin's account of sovereignty, see generally, DENNIS LLOYD, THE IDEA OF LAW 177-78 (1991).

81. Tarullo, supra note 5, at 492 ("[T] involve companies from countries that already have competition laws."). The European Union is powerful economically and, therefore, powerful in international trade and antitrust, but not militarily. See, e.g., Robert Kagan, Of PARAdISE AND POWER: AMERICA AND EUROPE IN THE NEW WORLD ORDER 19-42 (2003).

82. Compare Slaughter, A Global Community of Courts, supra note 7, at 218.

83. Richard A. Falk, The Relevance of Political Context to the Nature and Functioning of International Law: An Intermediate View, in THE RELEVANCE OF INTERNATIONAL LAW 133, 142 (Karl W. Deutsch \& Stanley Hoffmann eds., 1968); see Anne-Marie Slaughter Burley, International Law and International Relations Theory: A Dual Agenda, 87 AM. J. INT'LL. 205, 205 (1993).

84. THOMAS M. FRANCK, FAIRNESS IN INTERNATIONAL LAW AND INSTITUTIONS 7-9 (1995). 
decision. ${ }^{85}$ The "legalization" 86 of international law therefore does not necessarily entail restraint of powerful governments and the interests they represent, ${ }^{87}$ but, at least in antitrust, their protection. ${ }^{88}$ It is therefore no wonder that Slaughter has argued that "many commentators denounced the renewed presumption of territoriality as a giant step backwards to a rigid and out-moded principle that would handicap U.S. law-enforcement efforts." 89

\section{B. Why are the Outcomes of Merger Proceedings Different?}

The problem, which stems from the extraterritorial effect where parties (i.e., governments) involved in the dispute as a result of different enforcement ${ }^{90}$ are on an equal footing, is that two or more decision-makers deciding on the same matter will often make different decisions in hard cases. When a foreign agency prohibits a transaction, or allows it only under imposition of heavy remedies, a dispute on enforcement occurs if the domestic agency clears the same transaction. Extraterritorial effect is therefore a constant potential cause for dispute. The goal of agencies in both jurisdictions is to protect consumers. ${ }^{91}$ Why then are the outcomes of merger proceedings different?

As a result of the extraterritorial effect it is possible that decisions will be different if investigations are made into different markets with different market situations. A corporation might have a different position on different markets. Nonetheless, different market situations do not appear to have been the key problem in the two big merger cases. ${ }^{92}$ Different enforcement and doctrinal approaches, though based on relatively similar legal norms, ${ }^{93}$ were cited in addition to national bias ${ }^{94}$ as the most important reasons for diverging opinions.

85. See infra Part III. B.

86. Compare Slaughter, supra note 6.

87. According to liberal international relations theory, states are the agents of individual and group interests. This means that the law designed to achieve specific international outcomes does not have states as its subjects, but rather the individuals and groups that states are assumed to represent. See Slaughter, Liberal Intemational Relations Theory and International Economic Law, supra note 7, at 729.

88. Compare Slaughter, supra note 6 , at 210.

89. Slaughter, Liberal International Relations Theory and International Economic Law, supra note 7, at 736.

90. See Franck, supra note 25 , at 520 .

91. See, e.g., Francesco Guerrera \& Andrew Hill, US Official challenges Monti Claim, FIN. TIMES, May 9, 2002, at 7 (reporting that both European Commissioner Mario Monti and U.S. Department of Justice Deputy Attorney General William Kolasky claim that the goal of competition policy is the protection of consumers).

92. See Antitrust Division Submission for OECD Roundtable on Portfolio Effects in Conglomerate Mergers, Range Effects: The United States Perspective, at http://www.usdoj.gov/ atr/public/international/9550.pdf (last visited Oct. 4, 2004) [hereinafter Roundtable on Portfolio Effects].

93. See generally Thomas E. Kauper, Merger Control in the United States and the European Union: Some Observations, 74 ST. JoHN's L. REV. 305, 312 (2000).

94. See infra Part III. A. 
Standards of merger review are different in different jurisdictions. ${ }^{95}$ Even within jurisdictions, it is not always clear which standard to use and how to use them. ${ }^{96}$ The Canadian discussion on whether to adopt a "total surplus" or "consumer surplus" standard ${ }^{97}$ or the fact that the FTC and the Department of Justice, which have long had concurrent authority, have not always agreed with each other ${ }^{98}$ are most instructive in this respect. In light of the comments above regarding power and the ability of the powerful to enforce their decisions, Japan surprisingly does not exercise its extraterritorial effect. ${ }^{99}$ This is because the principle of consumer welfare has not retained the same importance in its antitrust laws, which effectively means voluntary taxation of domestic consumers for subsidy purposes. ${ }^{100}$

The problem of different approaches is particularly troublesome in the area of merger review, where theories underlying decisions have shown a history of significant change, ${ }^{101}$ making consensus on the correct theories even more difficult. As competition policy changes with new market conditions and new learning in economics, specifying binding antitrust rules with too much precision would be misguided. ${ }^{102}$ Similarly, Janow suggests that although

95. Fiebig divides the existing merger control regimes into three categories based on their substantive standard of review: "(1) regimes which prohibit the creation or strengthening of a dominant position (2) regimes which prohibit the substantial lessening of competition [or] (3) regimes which consider both the effect on competition and other policy concerns." See Fiebig, supra note 11 , at $252-53$.

96. Eleanor M. Fox, U.S. and European Merger Policy-Fault Lines and Bridges Mergers That Create Incentives for Exclusionary Practices, 10 GEO. MASON L. REV. 471, 475 (2002) (arguing that "[i]n a given hard case, different outcomes may follow from indeterminate economics or different orientations of American jurists").

97. See Commissioner of Competition v. Superior Propane Inc., [2003] 3 F.C. 529 (Can.), available at http://decisions.fct-cf.gc.ca/fct/2003/2003fca53.html (last visited October 4, 2004).

98. See Donald L. Flexner \& Mark A. Racanelli, Merger Control and State Aids Panel: State And Federal Antitrust Enforcement in the United States: Collision Or Harmony?, 9 CONN. J. INT'L L. 501, 502 (1994).

99. A recently concluded agreement between the European Union and Japan may nonetheless indicate a move in a different direction. See Agreement Between the Government of Japan and the European Community Concerning Cooperation on Anticompetitive Activities, Sept. 10, 1994, http://europa.eu.int/comm/competition/international/bilateral/japan/inv_en.pdf (last visited October 4, 2004).

100. Diane P. Wood, International Competition Policy in a Diverse World: Can One Size Fit All? In 1991 FORDHAM CORP. L. INST., EC AND US COMPETITION LAW AND POLICY 71-85 (Barry E. Hawk ed. 1992), reprinted in JOHN H. JACKSON ET AL., INTERNATIONAL ECONOMIC RELATIONS 1128-29 (4th ed. 2002).

101. Id. at 1127 ("American antitrust has changed, and changed again, over its century of existence, in the way that it approaches business practices and the precise practices that it condemns."). For the changed U.S. attitude to the range effects theory, see Roundtable on Portfolio Effects, supra note 92.

102. Tarullo, supra note 5, at 478; cf. Morris R. Cohen, The Process of Judicial Legislation, 48 AM. L. REv. 161, 184-185 (1914) ("To make a detailed description of specific human actions forbidden or allowed and their consequences would be an endless and impossible task."). 
cross-fertilization is constructive and important, it seems unlikely to ever be complete. $^{103}$

Furthermore, abstract legal rules and economic analysis cannot be separated from political life and society. Even if standards are unified in all jurisdictions, there will be no "one right answer"104 in each of them. Antitrust has always interacted with ideology. ${ }^{105}$ Belief in the autonomy of the economic sphere is erroneous, as economic life is dependent on and conditioned by a framework that is moral, political, social, and legal. ${ }^{106}$ In the quest for the universal, it should not be forgotten that a nation's values on resource allocation, social preferences, economic freedoms, and cultural matters have a critical role to play in shaping both its competition and its enforcement policies. ${ }^{107}$

Dworkin is the only one (beside the Langdellian formalists) to claim that there is "one right answer" to a legal dispute in "hard cases." Nevertheless, even his account of the "one right answer" rests on the premise of the right answer within a particular legal system. His dimension of "fit" assumes that one political theory is pro tanto a better justification in a modern, developed, and complex system. The second dimension-the dimension of political morality-supposes that if two justifications provide an equally good fit with the legal materials, one nevertheless provides a better justification than the other if it comes closer to capturing the people's rights within a complex and comprehensive legal system of a particular jurisdiction. ${ }^{108}$ Though Slaughter conceded that "no one answer is the right one"109 and many times emphasized that her model is rooted in the pluralism of multiple legal systems, ${ }^{110}$ she largely ignores both the argument of fit and of political morality and argues that, as choice of law principles converge, the particular forum in which a dispute is heard will become increasingly irrelevant. ${ }^{111}$ It follows that, regardless of the

103. Janow, supra note 4, at 51 .

104. Ronald DWORKIN, A MatTer of PRINCIPLE 143-45 (1985).

105. See, e.g., ROBERT H. BORK, The ANTITRUST PARADOX: A POLICY AT WAR WITH ITSELF 10 (1993) (referring to antitrust as a subcategory of ideology, as a microcosm in which larger movements of our society are reflected, and perhaps, in some small but significant way, reinforced or generated).

106. Compare Wilhelm Röpke, Economic Order and International Law, in RECUEIL DES Cours: Collected COURSES OF THE HAGUE ACADEMY OF INTERNATIONAL LAW 209, 209-10 (Académie de Droit International ed., 1954).

107. Richard B. Bilder \& Susan L. Karamanian, Recent Book on International Law: Book Reviews, 96 AM. J. INT'L L. 1012, 1015 (2002) (reviewing MARK R. JOELSON, AN InTERnational antitrust Primer: A Guide to the Operation of the UnIted States, EUROPEAN UNION, AND OTHER KEY COMPETTTION LAWS IN THE GLOBAL ECONOMY (2001)). For a similar argument, see Wood, supra note 100 (arguing that one size may not fit all).

108. DwORKIN, supra note 104, at 143-145.

109. Slaughter, A Global Community of Courts, supra note 7, at 203.

110. Id. at $203,217,219$.

111. Id. at 209. 
extent to which laws are harmonized, ${ }^{112}$ extraterritorial effect will create disputes arising from different enforcement in different jurisdictions.

Furthermore, American and E.U. procedural systems are different and a source of mistrust, ${ }^{113}$ but even if they are completely harmonized the problem of different decision-making will not be alleviated. This is not to say that procedural harmonization, such as harmonization of the notification procedure, would not help the business community to cope with different procedural systems. ${ }^{114}$ It merely means that neither harmonization of substance nor of process will help create the same outcomes in hard cases when decisions are taken against the background of a different legal system.

\section{What if all Countries Were to Adopt Antitrust Laws and Enforce Them Extraterritorially?}

The question arises whether all countries should be able to exercise extraterritorial effect. Tarullo argues that antitrust problems do not currently pose the kind of threat to world economic welfare that requires a response, so the approach to antitrust problems should be more incremental than dramatic. ${ }^{115}$ But he also admits that they may increase as international economic transactions continue to increase relative to overall economic activity. ${ }^{116}$ This may be true at the current time (although Tarullo's Article came before the $G E / H o n e y w e l l$ dispute).

In order to enable small countries to exercise their extraterritorial effect, Dodge proposes reciprocal enforcement of antitrust judgments ensured by a Hague convention, so the assets available for enforcing any country's

112. Contra Slaughter, Liberal International Relations Theory and International Economic Law, supra note 7, at 740 ("Over the long term ... bringing the conflict to this kind of a head is likely to invite Executive intervention to reach an agreement harmonizing the laws in question or establishing mutually agreed principles for interpretation and application of those laws.").

113. In the United States, regulators must bring an action in federal court to have the transaction enjoined. The European Commission does not need to seek judicial approval to block a proposed transaction-it may do so directly. Jack Welch complained that in the European procedure, "the prosecutor is also the judge." Jack Welch, The Prosecutor is Also the Judge, TiME, Jul. 16, 2001, http://www.time.com/time/magazine/story/0,9171,1101010716$166688,00 \mathrm{html}$. Although the Commission's decisions can be challenged in the Court of First Instance and appealed to the ECJ, the petitioning parties may be reluctant to appeal given the time and cost involved and minimal likelihood of success. See Erin E. Holland, Note, Using Merger Review to Cure Prior Conduct: The European Commission's GE/Honeywell Decision, 103 COLUM. L. REV. 74, 78 (2003).

114. See, e.g., Janow, supra note 4, at 48-50 (arguing that it would appear highly desirable to harmonize the essential rules on merger control procedures); Jürgen Basedow, Conflict of Laws, Comparative Law and Civil Law: International Antitrust: From Extraterritorial Application to Harmonization, 60 LA. L. REV. 1037, 1051 (2000) (arguing that "states should conclude a multilateral convention establishing some basic procedural duties of notification, information and consultation.").

115. Tarullo, supra note 5 , at 479.

116. Id. 
judgments would increase to include the defendant's assets in any country that is a party to the convention. With respect to both jurisdiction and enforcement, the size advantage and economic power of the United States and the European Union would be stripped away. ${ }^{117}$ Dodge favors the spread of extraterritorial effect in the name of fairness, ${ }^{18}$ but his proposal, combined with the fact that merger review deals with probabilities not certainties, ${ }^{119}$ and that different decisions are bound to occur, would bring all governments and the interests they represent to the same level, and lead to the dispute-generating mechanism of the twenty-first century.

If everyone were empowered to exercise extraterritorial effect, there would be many more disputes. ${ }^{120}$ As there would be more decision-makers judging the same transaction, the chances of someone exercising their veto right would increase significantly. A “'litigation' explosion" would render visible what was there all along. ${ }^{121}$ With more and more developing countries drafting antitrust legislation, the problem of greater numbers of regulators will only increase. Prior to 1990 , only twenty-eight countries had some form of antitrust or competition legislation. Today more than eighty countries ${ }^{122}$ have such laws, and at least twenty more are in the process of drafting them. ${ }^{123}$

The proposal to allow all nations to exercise extraterritorial effect brings us to another contradiction. The question of whether forms of competition common in the developed world would benefit the developing world is beyond the scope of this Article, but it appears that many global policy-makers believe that a free market, coupled with antitrust law, benefits their development. ${ }^{124}$ Not all scholars would agree, ${ }^{125}$ although no one has disputed that developing

117. Dodge, supra note 28 , at $387-89$.

118. Id. at 390 .

119. See StEPHEN F. Ross, Principles of ANTITRUST LaW 2 (1993) ("The best experts can only assert probabilities or tendencies, not certainties. Whether courts should prohibit conduct as violative of the antitrust laws thus necessarily turns on a third value judgment, about the degree of certainty that should be required before an individual is prohibited from freely pursuing private goals.").

120. Compare Slaughter, A Global Community of Courts, supra note 7, at 218.

121. KENNEDY, supra note 33, at 91 .

122. "Approximately 80 WTO Member countries, including some 50 developing and transition countries, have adopted competition laws ...." WTO, Trade and Competition Policy: Working group set up by Singapore Ministerial, at http:/www.wto.org/english/thewto_e/ minist_e/min99_e/english/about_e/16comp_e.htm (last visited Nov. 22, 2004).

123. See Barry A. Pupkin, The Internationalization of Antitrust Law and the Increased Convergence of US and EU Antitrust Law (Jan. 16, 2001), at http://www.ssd.com/ files/tbl_s29Publications/FileUpload5689/8799/pupkin.pdf (last visited Nov. 22, 2004).

124. Communication from the European Community and its Member States, Working Group on the Interaction between Trade and Competition Policy, May 25 1999, WT/WGTCP/W/115 ("The discussions in the Group have shown that there is a general recognition that competition policy should be considered as a tool for development."); see also Shyam Khemani, Competition Policy: An Engine for Growth, GloBal CoMP. Rev. 20, 23 (1997).

125. For the opinion that forms of competition known by the developed countries are not perfect for the developing world, see, e.g., ALICE AMSDEN, THE RISE OF 'THE REST' - 
countries require a strong international antitrust regime to protect them against foreign action. ${ }^{126}$

In Slaughter's interest analysis, developing countries must adopt antitrust laws in their national legislation, otherwise they would have no substantive interest in the case, and their laws would never be applied. ${ }^{127}$ Furthermore, their forum may never be the most appropriate, even under the first step of Slaughter's test, which is met by determining whether the suit states a claim on which relief may be granted under their law. ${ }^{128}$ This is logical, as their internal law could not be applied due to the lack of antitrust legislation. In the language of the classical interest analysis, by choosing their laws or forum, their competing policy would not be furthered ${ }^{129}$ as they have no antitrust policy.

However, this would force them to pass antitrust laws and embrace neoliberal economics only to protect them against foreign acts. If they are not enforcing antitrust internally, they lack an "interest" in the enforcement of antitrust in transnational relations. And the enforcement stakes can be high. ${ }^{130}$ Similarly, should antitrust be incorporated into the WTO, as proposed by the European Union, ${ }^{131}$ the only consequence may be the introduction of antitrust law to countries that do not need it. Even worse, it may hamper their development. ${ }^{132}$ Thus, a WTO norm, or the above-mentioned interest analysis, might lead to undesired side-effects.

\section{Positive Comity}

Is positive comity a solution to disputes caused by the extraterritorial effect? Positive comity is based on the recognition that anticompetitive

ChAL LENGES to THE WeSt From LATE INDUSTRIALIZING ECONOMIES 140 (2001) (arguing that the "Latecomer" (successful countries of East Asia) forms of competition were different than the ones the West had known, and argues that in theory and practice, the nature of competition varied historically. Perfectly competitive markets may have made the North Atlantic rich, but they were fundamentally dysfunctional in "the rest" for most of the half century after World War II).

126. See Andrew T. Guzman, International Antitrust and the WTO: The Lesson from Intellectual Property, Berkeley Program in Law \& Economics, Working Paper Series. Paper 36, 12-13 (Nov. 7, 2000), http://repositories.cdlib.org/blewp/36 (arguing that the developing countries would be in favor of a strong international antitrust regime).

127. Slaughter, Liberal International Relations Theory and International Economic Law, supra note 7, at 742 ("The existence of national legislation is the best indicator of those interests.").

128. Id. at 737-39.

129. Bruce Posnak, Choice Of Law-Interest Analysis: They Still Don't Get It, 40 WAYNE L. REV. 1121, 1125 (1994); see infra Part II. D.

130. See supra Part II. A. Compare Slaughter, A Global Community of Courts, supra note 7, at 212 ("Contrary to appearances, however, adequate forum determinations do not depend on first world versus third world status. Determinations of outright bias or other corruption are relatively rare."). For questions of national bias, see infra Part III. A.

131. See Sir Leon Brittan, Vice-President of the European Commission, The Need for a Multilateral Framework of Competition Rules, Address Before the OECD Conference on Trade and Competition (June 30, 1999) (transcript on file with author).

132. See AMSDEN, supra note 125 , at 140. 
activities occurring within the territory of one party to the agreement may adversely affect the interests of another party. ${ }^{133}$ It means that a party to an agreement invokes, upon request of another, its domestic competition law to remove anticompetitive practices that occur within its jurisdiction and that adversely affect another party's interests. ${ }^{134}$ The desired end result is that only one forum decides, so the problem of increased numbers of decision-makers is alleviated. ${ }^{135}$

Positive comity does not yet apply to merger review. This is not because the concept itself could not be applied to mergers, but rather "because of the short statutory deadlines on both sides of the Atlantic."136 The proposal for application of positive comity to mergers, which calls for increased crossborder cooperation among competition enforcement agencies in the area of merger review, includes: "The adoption of work-sharing arrangements among enforcement agencies, whereby in most cases remedial steps taken by the agency in the jurisdiction having the greatest interest in a particular merger will be deemed sufficient to satisfy competition problems in all jurisdictions having an interest in the transaction ...., 137 This stems from the mistaken belief of interest-balancing inherent in the concept of positive comity. Positive comity has invited both criticism ${ }^{138}$ and praise. ${ }^{139}$ However, positive comity, in its balancing of interests approach, is jurisprudentially false, and thus, a "paper rule" 140 in international antitrust without any real effect.

It is impossible to determine which jurisdiction has a greater interest in the outcome of the investigation under positive comity and Slaughter's liberal international relations test, which assesses the true configuration of state

133. See James F. Rill et al., Case Study: The Amadeus Global Travel Distribution Case, in ANTItrust Goes Global: What Future For Transatlantic CoOperation? 195, 195 (Simon J. Evenett et al. eds., 2000).

134. European Communities - United States Agreement on the Application of Their Competition Law, Sept. 23, 1991, U.S.-EC, 30 U.S.T 1487, art V, 1497-98 [hereinafter Agreement on the Application of Competition Laws].

135. See Devuyst, supra note 12 , at 136.

136. See Janow, supra note 4, at 33.

137. Edward M. Graham, Economic Considerations in Merger Review, in ANTTTRUST GOES Global: What Future for Transatlantic CoOperation? 57, 76 (Simon J. Evenett et al. eds., 2000).

138. See, e.g., Mitsuo Matsushita, Intemational Cooperation in the Enforcement of Competition Policy, 1WASH. U. GLOBAL STUD. L. REV. 463, 471 (2002) (arguing that positive comity "is out of the question" when competition policies of two countries are "entirely inconsistent with each other"); James R. Atwood, Positive Comity-Is it a Positive Step?, 1992 FORDHAM CORP. LAW INST. 79, 87-88 (Barry E. Hawk ed., 1993) (arguing that positive comity could only work where both governments involved already have a direct interest in prosecuting because the behavior in question directly affects them, in which case, cooperation is likely to occur anyway, and any desire to undertake an investigation on behalf of a foreign government risks a domestic backlash).

139. See Dodge, supra note 28 , at 387 (noting that "the U.S. Department of Justice continues to trumpet positive comity as a success").

140. Llewellyn, supra note 9, at 1237. 
interests-that is to say the actual interests of individuals and groups as represented by the state. ${ }^{141}$ This becomes particularly clear if the enquiry is moved away from the classic billiard ball of the state, ${ }^{142}$ and focuses from a liberal perspective on groups with an interest in the outcome of merger review or other investigation.

This test is problematic both politically and jurisprudentially. Though consumers are the ones who are supposed to be protected by antitrust laws, ${ }^{143}$ the interest of jurisdictions in merger review extends far beyond them. ${ }^{144}$ Which country's shareholders, workers, competitors, and consumers have the bigger interest? Will a Brussels or Washington law firm or office deal with the case? Whose desire to win the case (i.e., receive or not receive the merger clearance or have the outcome of the cartel investigation be an enormous fine or not) is greater? Who has the greater desire to keep, get, or lose their job at the outcome of the investigation? ${ }^{145}$ All the consequences of a merger are difficult to predict, even to the merging parties themselves. ${ }^{146}$ The precise economic repercussions of a merger on society are impossible to determine ${ }^{147}$ irrespective of whether a particular constituency, including all consumers, competitors, and workers, emanates from one jurisdiction, or whether the workers, shareholders, voters, and management of the merging parties come from different jurisdictions. In either case an unquantifiable interest will be weighed. Furthermore, economic forces flow with great rapidity from one country to the next, and often-discussed concepts such as sovereignty and independence can mislead when applied to today's world economy. ${ }^{148}$ One could not possibly distinguish whether consumers, competitors, and employees in the European

141. Slaughter, Liberal International Relations Theory and International Economic Law, supra note 7, at 736-37.

142. Slaughter, supra note 6 , at 34 .

143. According to the Chicago School, "the exclusive goal of antitrust adjudication ... is the maximization of consumer welfare." See, e.g., BORK, supra note 105, at XI.

144. Infra notes 165-69 and accompanying text.

145. Jack Welch, for instance, wrote a book, JACK: WHAT I'vE LEARNED LEADING A GREAT COMPANY AND GREAT PEOPLE (2001), on his path to retirement. Can his - overly represented interest in comparison to CEOs of much smaller corporations or small consumers who are, in most cases, blissfully unaware of the consequences of a merger, cartel investigation, etc., be weighed against the interest of these consumers or other CEOs and workers who, as a consequence of a prohibition, retained/lost their jobs? Compare Moravcsik, supra note 32, at 518 (arguing that every government represents some individuals and groups more fully than others).

146. See Linda Corman, Left at the Altar (Failure of Some Merger Agreements), MAGAZINE FOR SENIOR OfFICIALS, June 1998 (explaining that many merger deals do not go through, sometimes despite the regulators' approval, as was the case in the failed BT/MCI merger, because previously unknown information appears or simply because of the unpredictable market).

147. KENNEDY, supra note 74, at 287-88 (arguing that efficiency does not "produce clear answers to the question what rules will maximize consumer welfare, let alone a dynamic theory of welfare over time").

148. JOHN H. JACKSON ET AL., INTERNATIONAL ECONOMIC RELATIONS 1 (4th ed. 2002). 
Union or the United States had a bigger interest in the Boeing/MCD or GE/Honeywell mergers. Would the United States have a bigger interest than the European Union in a merger between British Airways and American Airlines? ${ }^{149}$

Currie's traditional conflict of laws interest analysis ${ }^{150}$ differs from the proposed interest-balancing approach. The interest of the jurisdiction under positive comity and Slaughter's suggestion is the interest in the outcome of the merger review or other antitrust investigation. This makes the two tests completely different, and indeed the latter impossible. As Posnak writes, "an interested state" in a conflict of laws is one whose competing law policy would be furthered if that law were applied-nothing more and nothing less. "A state may have an 'interest' even if it has no interest in [the outcome of] the case ...." Slaughter, however, in establishing jurisdiction, ${ }^{152}$ presupposes the balancing of interests in the litigation's outcome or antitrust investigation. According to Slaughter, interest cannot be measured by contacts with territory per se. ${ }^{153}$ From a liberal perspective, the real measure of "state" interest is the interest of whichever segment of society the state represents. The state's interest will vary to the extent that the individuals making up this segment are affected. It is therefore important to examine the actual interests of individuals and groups as represented by the state, as well as how far they extend. ${ }^{154}$ These interests are the economic and political interests ${ }^{155}$ of subgroups in a society, and are interests in the outcome of the case. They are, however, impossible to quantify or balance.

Furthermore, there are vast economic and, consequently, political stakes in merger review. A merger dispute between the European Union and the United States by definition cannot be smaller than the threshold that the European Union is imposing in order to invoke its competence. ${ }^{156}$ As for the

149. Flag carriers are one of the most vivid examples of impossibility to balance interests. For more on the potential merger, see Possible American Airlines-British Airways Merger, http://www.americanbritishairways.com/newsroom/recentarticles/dji080301.htm (on file with author).

150. Posnak, supra note 129 , at 1123-32.

151. Id. at 1125 .

152. Slaughter, Liberal International Relations Theory and International Economic Law, supra note 7 , at 737 .

153. See id. See also Slaughter, A Global Community of Courts, supra note 7, at 210.

154. Slaughter, Liberal International Relations Theory and International Economic Law, supra note 7, at 736-39.

155. Compare Burley, supra note 62, at 1963 ("[J]udges respond . . to individualized assessments of the particular economic or political interests at stake on the facts of a given case.").

156. The European Union's thresholds are higher than the ones in the Clayton Act. The European Commission does not hear a case unless a combined aggregate turnover of all the undertakings concerned is more than $\mathbf{5 0 0 0}$ million Euros and the aggregate Community-wide turnover of at least two of the undertakings concerned is more than 250 million Euros, unless each of the undertakings concerned achieves more than two-thirds of its Community-wide turnover within one and the same Member State. See Council Regulation 139/2004, 2004 O.J. 
Boeing/MCD merger, it has been estimated that between 1970 and the early 2020 s, Airbus's entry will have reduced Boeing's profits by $\$ 100$ billion. $^{157}$ Any Airbus profits will have been achieved at the considerable expense of the shareholders of the Boeing Corporation, and perhaps the taxpayers of the United States. ${ }^{158}$ Additionally, in the European Union, the aircraft industry employs 500,000 people. It is an industry in expansion and its technology affects many other industries. This is of essential importance in an age in which many labor-intensive industries are moving to the Third World. ${ }^{159}$ Thus, it is difficult to imagine that a competition authority would defer its decision to a regulator who has an unquantifiably "greater" interest in the outcome of the case. As there is no one right answer in hard cases, relinquishing the veto right $^{160}$ is even more problematic.

Moreover, as Slaughter argues, interests cannot be defined by what a state claims in the context of a particular case, as state institutions have little to lose by identifying their interest with that of the individual litigant. There is no consensus on giving decision-making powers even to an "impartial" international organization, let alone to a state protecting opposite, or at least divergent, interests. ${ }^{161}$ Acquiescence regarding the fact that another jurisdiction has a bigger interest in the outcome would also mean a dangerous qualitative step towards the substantive outcome of cases. Indeed, an economic analysis and projection resembling that in the actual merger review would be necessary in order to determine what economic consequences a merger would have on consumers in a particular territory.

In Amadeus Global Travel Distribution Case, ${ }^{162}$ a positive comity request was made precisely because both jurisdictions had an interest, but only the European Commission could effectively prosecute. Positive comity is thus useful only for enforcement purposes, where one of the jurisdictions is otherwise unable to prosecute anticompetitive behavior. For instance, if consumers will be negatively affected in one of the jurisdictions, and "anticompetitive activities at issue do not have a direct, substantial, and reasonably foreseeable impact on the requesting party's consumers,"163 assuming the goal of antitrust is to protect consumers, the requesting party's agency will not be able to write a decision based on anticompetitive effects on

(L 24) 1 [hereinafter European Merger Regulation]. The previous merger regulation from 1989 contained the same thresholds. See Council Regulation 4064/89, 1989 O.J. (L 395) 1. Member states' competition authorities are competent in cases below this threshold.

157. Damien Neven \& Paul Seabright, European Industrial Policy: The Airbus Case, 10 ECON. POL'Y 313, 319 (1995).

158. Id. at 344.

159. See Nicolas Moussis, ACCESS to EuRopean UNion 333 (1999).

160. Evenett et al., supra note 22, at 21.

161. See, e.g, Janow, supra note 4, at 51 ("Few national authorities (or legislative bodies) are willing to sign away authority to review a transaction if domestic competitive effects are implicated or local firms are potentially affected.").

162. See, e.g., Rill et al., supra note 133, at 195-98.

163. Devuyst, supra note 12, at 136. 
their territory. ${ }^{164}$ This is why in Amadeus, one cannot talk about deferral, as the FTC did not have the power to enforce anything, and thus had nothing to defer nor any right of enforcement to relinquish.

Furthermore, there was no balancing of interests in regard to which jurisdiction had a bigger interest. American consumers had no direct interest, but the United States' jurisdiction still had an immeasurable interest in the outcome of the investigation. Otherwise, the FTC would not have made the request. ${ }^{165}$ This further shows that the interest of the jurisdiction goes well beyond the interest of consumers, although antitrust authorities in the two major jurisdictions are always keen to assert that consumer protection is the sole goal of their competition policy. ${ }^{166}$ It is therefore not surprising that the Agreement Between the Government of the United States of America and the European Communities Regarding the Application of Their Competition Laws states that a party may request initiation of enforcement activities if "its important interests" are adversely affected, and not if "the important interests of the consumers on its territory" are adversely affected. ${ }^{167}$

Moreover, as Duncan Kennedy explains, the outcome of adjudication, a particular rule definition, be it by an administrative agency or an appellate court, is important not only to individual litigants but is also an important "stake" to the opposing intelligentsia. ${ }^{168}$ Similarly, this shows that the outcome of adjudication has wider repercussions in a society than the mere interests of individual litigants or corporations involved in alleged anticompetitive activity, although sometimes the direct stakes for the others are solely ${ }^{169}$ ideological and do not have a direct economic consequence. In Amadeus, both jurisdictions

164. As Fiebig realized, "it is much easier to identify which merger will not be of legitimate concern to national regulators than to identify which mergers will be of legitimate concern for national regulators" and should thus be prohibited. Fiebig, supra note 11, at 253 . This effectively means that it is easy to recognize if there is no interest at all, but more difficult to recognize how big the interest is, if it is actually present.

165. Under Article $\mathrm{V}$, the basic prerequisite for the agency to make a request is to have an important interest. Agreement on the Application of Competiton Laws, supra note 134, at 1497-98.

166. See Guerrera \& Hill, supra note 91; see also Edward T. Swaine, "Competition, Not Competitors, "Nor Canards: Ways of Criticizing the Commission, 23 U. PA. J. INT'L. ECON. L. 597, 604 (2002) (arguing that the United States' claim that the European Commission inappropriately concerns itself with competitors, not competition, is "perhaps the single most quoted aphorism in U.S. antitrust jurisprudence").

167. See Agreement on the Application of Competition Laws, supra note 134; see also Agreement Between the European Communities and the Government of the United States of America on the Application of Positive Comity Principles in the Enforcement of Their Competition Laws, June 4, 1998, Preamble, U.S.-EC, 37 I.L.M. 1071 [hereinafter Agreement on Positive Comity Principles].

168. KENNEDY, supra note 74 , at $43,64,67$. Kennedy also argues that "[i]deological intelligentsias would be 'interested' in appellate adjudication even if judges made rules by tossing coins, for the simple reason that these coin tosses would dispose of significant stakes." Id. at 69 .

169. The word "solely" is used in this sentence in the antitrust context, because in this field of law, as also in many others, ideological stakes are usually coupled with vast economic stakes. 
and their respective governments had an interest. Which party to the agreement or dispute had a bigger interest could not be determined and was not even attempted.

Slaughter again defended the concept of interest analysis in establishing the most suitable forum. ${ }^{170}$ Referring to Spiliada Maritime Corp. v. Cansulex, ${ }^{171}$ and to a line of other cases, she argued that in establishing jurisdiction courts take into consideration the "interest of all the parties" as opposed to the "territorial theory of jurisdiction."172 She claimed "there has been a distinct shift toward the recognition, on a case by case basis, of a 'natural' or 'most appropriate' forum among the courts of the world."173 However, cases such as Spiliada ${ }^{174}$ address the issue of forum non conveniens, where courts place importance on issues such as the availability of witnesses, legislation governing relevant transactions, and the place where the parties reside and carry on their business. ${ }^{175}$ This enables the parties to more easily exercise their (procedural) rights. This is not because parties from one jurisdiction would have a bigger substantive interest in the outcome of the process, which was Slaughter's liberal international relations suggestion ${ }^{176}$ and what the concept of positive comity presupposes. The latter concepts cannot develop on a case-by-case basis or any other basis.

In addition, forum non conveniens is not a solution to the problem caused by the extraterritorial effect, as a particular jurisdiction may use its extraterritorial effect despite the facts which are taken into consideration in the forum non conveniens approach. The core idea of the extraterritorial effect is to regulate activity outside domestic territory as it impacts on the enforcer's jurisdiction. Thus, the fact that it is more convenient for the parties to exercise their rights in a particular forum becomes completely irrelevant.

\section{E. Is Cooperation Enough?}

As has been seen, simple abstract policy convergence will not prevent different decisions. ${ }^{177}$ Can cooperation on concrete cases achieve such a result?

170. Slaughter, A Global Community of Courts, supra note 7, at 205-19.

171. Spiliada Maritime Corp. v. Cansulex Ltd., 1 A.C. 460, 476 (H.L. 1987).

172. Slaughter, A Global Community of Courts, supra note 7, at 209-10.

173. Id. at 210 .

174. Spiliada Maritime Corp., 1 A.C. at 476. The Spiliada case contains the slogan that a foreign forum may be more suitable "for the interests of all the parties and the ends of justice." Id.

175. See, e.g., Ronald A. Brand, Comparative Forum Non Conveniens and the Hague Convention on Jurisdiction and Judgment, 37 TEX. INT'L. L.J. 467, 471-74 (2002).

176. See Slaughter, Liberal International Relations Theory and International Economic Law, supra note 7, at 736-39.

177. See supra Part II. B. See also Charles A. James, Assistant Attomey General, Antitrust Division, U.S. Department of Justice, Reconciling Divergent Enforcement Policies: Where Do We Go From Here?, Address presented at the Fordham Corporate Law Institute 28th Annual Conference on International Law and Policy (October 25, 2001), at http://www.usdoj.gov/ 
"[I]nternational law is not a simple abstraction such as 'the law governing relations among states,' but is instead 'a set of particular human projects situated in time and place." "178 In line with this argument, it is not up to the agreements that will determine the outcome of the cooperation, but rather the actual concrete project of cooperation or dispute resolution.

Bilateral cooperation has been developed particularly in relations between the European Union and the United States, ${ }^{179}$ which is not surprising, as they are the only ones who are truly involved in international antitrust discourse. Cooperation is of extreme importance for effective prosecution of international cartels, since much of the alleged conduct takes place outside domestic territory and much of the evidence is located beyond the domestic regulator's reach. ${ }^{180}$ It is also extremely important in order to avoid both duplication of work and the reaching of divergent decisions. ${ }^{181}$

In the Boeing/MCD decision, the Commission stated that it complied with all the regulations of the Agreement between the Government of the United States of America and the Commission of the European Communities Regarding the Application of Their Competition Laws. Nevertheless, requirements of notification, ${ }^{182}$ exchange of information ${ }^{183}$ where the actions of one country's regulators may affect the other country's interests, cooperation, coordination in enforcement activities, ${ }^{184}$ and consultation ${ }^{185}$ were obviously not

atr/public/speeches/9395.htm.

The sometimes blurry line between antitrust enforcement and economic regulation leaves considerable room for interpretation in the formation of competition law doctrine, and in the exercise of appropriate prosecutorial discretion. Thus, jurisdictions with facially similar competition laws can have significantly divergent policies and reach different conclusions, depending upon how each agency interprets its mandate to protect competition. If these areas of divergence overtake our zone of commonality, multi- jurisdictional competition law enforcement can frustrate, not facilitate, free trade flows ....

Id. For a contrary opinion, see Tarullo, supra note 5, at 496 ("The regulatory-convergence approach holds the most promise for dealing with transnational anticompetitive conduct.").

178. Benedict Kingsbury, Foreword: Is The Proliferation of International Courts and Tribunals a Systemic Problem?, 31 N.Y.U. J. INT'L L. \& POL. 679, 691 (1999).

179. See, e.g., Joint EU-US action plan, http://www.eurunion.org/partner/actplan.htm (last visited Nov. 27, 2004) (laying foundations for bilateral and multilateral cooperation in competition policy); Agreement on the Application of Competition Laws, supra note 134; USEU Merger Working Group, Best Practices on Cooperation in Merger Investigations, http://europa.eu.int/comm/competition/mergers/others/eu_us.pdf (n.d.) (last visited Nov. 27, 2004).

180. See, e.g., Klein, supra note 19 (noting that in the GE/DeBeers case, where the Department of Justice filed criminal antitrust charges against a U.S. company, "much of the alleged conduct relating to the cartel took place in Europe, and much of the evidence was located overseas and, consequently, beyond the Justice Department's reach.").

181. See Devuyst, supra note 12, at 132.

182. See Agreement on the Application of Competition Laws, supra note 134, art. II, at 1493-95.

183. Id. art. III, at 1495-96.

184. Id. art. IV, at 1496-98.

185. Id. art. VII at $1500-01$; cf. Guzman, supra note 5 , at 1145 : 
enough to prevent the different decisions. A new 1999 Agreement, supplementing the previous one, emphasizes positive comity, and contains an important article on the deferral or suspension of investigations in reliance on enforcement activity by the requested party. ${ }^{186}$ Arrangements on attendance in hearings and avoiding duplication of work were added. However, the $G E / H o n e y w e l l$ dispute ensued only two years later. In this case, "the two antitrust agencies reached fundamentally different conclusions despite analyzing the identical product and geographic markets, hearing the same arguments from parties and third-parties, considering the same theories of competitive harm, and largely having access to the same set of facts."187

Conflicts are most likely to arise in cases where either agency can make the decision without having to cooperate with the other. Unlike in other antitrust cases, ${ }^{188}$ merger review evidence is provided to the agency in the notification or a related document. ${ }^{189}$ Although disagreements on enforcement can arise in cartel investigations, just as they do in merger review, ${ }^{190}$ the drive to cooperate is stronger, because often the very precondition for enforcement in international cartel cases is cooperation. In addition, there is no veto right to block a transaction on another country's territory.

Although some scholars and officials argued that the Boeing/MCD dispute was an exception in generally cooperative transatlantic relations, ${ }^{191}$ and therefore not in need of a solution or conflict-based approach, ${ }^{192}$ the rhetoric changed significantly following the $G E / H o n e y w e l l$ dispute. It has since been acknowledged that inconsistent decisions can follow a period of tremendous cooperation, ${ }^{193}$ leading to the conclusion that cooperative efforts and good

[A]lthough ... bilateral agreements play an important role in the enforcement of antitrust laws, it is important to note that they do not go beyond the sharing of information. None of the agreements represent a compromise of domestic control over enforcement or any other loss of sovereignty. ... . There is no coordination of substantive laws, no establishment of minimum standards, and no accounting for the impact of one state's substantive laws on other states.

186. See Agreement on Positive Comity Principles, supra note 167, art. IV, at 1073-1074.

187. Roundtable on Portfolio Effects, supra note 92, at 20.

188. See, e.g., Tarullo, supra note 5, at 491.

189. See, e.g., European Merger Regulation, supra note 156, art. 11.

190. See, e.g., Fox, supra note 41, at 923 (noting that "Charles James, then an Assistant Attorney General in Charge of Antitrust, 'warned' Europe not to reprehend Microsoft for conduct allowed under U.S. law").

191. See, e.g., Tarullo, supra note 5, at 482 ("One is tempted to conclude that, for now, the Boeing case is an exception to the rule of productive consultation.").

192. See Devuyst, supra note 12 , at 142.

193. James, supra note 177.

Our experience with the proposed General Electric/Honeywell merger demonstrates, however, that close cooperation and goodwill between antitrust agencies does not guarantee consistent results in individual cases. A good working relationship cannot overcome significant differences in views about the proper scope of antitrust law in national and world markets. The U.S. and EU agencies reached inconsistent decisions despite a tremendous amount of coordination over several months. In fact, I do not believe that we could have worked together more closely. Our staffs talked on the phone frequently and had 
intentions are sometimes not enough. ${ }^{194}$

\section{NATIONAL BIAS AND INTERNATIONAL INSTITUTIONAL ARRANGEMENTS}

\section{A. National Bias or Perhaps a Different Doctrinal Approach?}

The question arises as to whether international law can deal with the problem of the polycentric world of decision-makers. If disagreement on enforcement cannot be solved by cooperation or positive comity, can it be solved ex post, after a decision is made?

Merger review is the most politically sensitive area of antitrust enforcement due to its immense impact on competitors, suppliers, customers, and local communities, and because it attracts wide publicity. ${ }^{195}$ It is no wonder that the question of national bias was at the forefront of both major merger disputes. Politicians, the press, and scholars had very different views of the disputed decisions and actions taken by regulatory bodies on each side of the Atlantic. Are there solid grounds for the allegations of national bias? Is different decision-making a consequence of different doctrinal approaches?

Boeing/MCD was the first case that nearly resulted in a trade war. When the FTC cleared the merger, they issued an unprecedented statement that "the national champion argument does not explain today's decision."196 Nevertheless, the press and politicians reacted fiercely to both decisions. ${ }^{197}$ The

extensive meetings in Washington and Brussels; the EC staff had access to our economic expert; and we had extensive substantive discussions at the very highest policy levels about the evidence and the theories the two agencies were pursuing. The glaringly inconsistent decisions, then, were not the product of a failure of co-operation or a lack of effort by either agency to ascertain the other agency's point of view.

Id.

194. Id.

Cooperative efforts and good intentions, however, are sometimes not enough.... This difference ... demonstrates that close cooperation and goodwill between antitrust agencies do not guarantee consistent results in individual cases. It would be hard to imagine how we could have cooperated more closely. Rather, it is a simple, but rather fundamental, doctrinal disagreement over the economic purposes and scope of antitrust enforcement.

Id. But cf. Anne-Marie Slaughter, The Accountability of Government Networks, 8 IND. J. GLOBAL LEGAL STUD. 347, 347 (2001) (arguing that regulatory agencies networking with their counterparts have created a web of fast, flexible, and effective relations); accord Kenneth W. Abbott, Recent Book on International Law: Book Review: Transatlantic Governance in the Global Economy, 98 AM. J. INT'L L. 220 (2004) (reviewing ANNE-MARIE SlaughtER, Transatlantic Governance in the Global Economy (Mark A. Pollack \& Gregory C. Shaffer eds., 2003)) (arguing that transgovernmental networks, "'the real new world order,' are normatively desirable because they are 'fast, flexible, and effective"').

195. See ERnEST Gellhorn \& William E. Kovacic, ANTtTRuSt LaW and Economics in a NUTSHELL 353 (4th ed. 1994) (1976).

196. In re Boeing, supra note 3.

197. "As confirming proof of their fears of political intervention, Americans could recite pledges by top EU officials to protect Airbus at all costs from U.S. efforts to safeguard American aerospace firms." William E. Kovacic, Transatlantic Turbulence: The Boeing- 
United States suspected that the European Union was seeking to protect the interests of Airbus Industries, while the European Union considered that the merger was favored by the United States because it would create a national champion. ${ }^{198}$ Scholars were divided. Sykes and Guzman supported the theory of national bias, ${ }^{199}$ while Kovacic and Fox argued that the difference between the decisions was primarily doctrinal. Fox maintained that, following precedent set by its earlier challenge to the Aérospatiale-Alenia/de Havilland merger, ${ }^{200}$ the European Commission was motivated by concerns of possible future predatory action by Boeing. ${ }^{201}$ Kovacic pointed out many adverse consequences on competition that were not taken into consideration by the FTC. $^{202}$ Nevertheless, he concluded that it was probably only the different doctrine that was causing the disputes. ${ }^{203} \mathrm{~A}$ similar story repeated itself in the GE/Honeywell merger. Despite fierce criticism of bias, ${ }^{204}$ Swaine did not

McDonnell Douglas Merger and International Competition Policy, 68 ANTrTRuST L.J. 805, 841 (2001). In contrast,

European government leaders were sure to view the US antitrust process through a lens shaped by longstanding US government hostility toward Airbus. They could recall how President Bill Clinton had criticized his immediate predecessors for doing too little to help American producers subdue Airbus and had promised that the Clinton administration would do more.

Id. at 840 . U.S. commentators were highly critical of the role Airbus, a European competitor of Boeing, played in the Commission proceedings, and the mutual recriminations were sharp and rancorous. Swaine, supra note 49 , at 630 . The competition between Boeing and Airbus was also a cause for dispute between the European Union and the United States before the GATT. In 1987 the United States accused the European Union of unfair government procurement. Further negotiations eased the tensions, but the dispute was never really settled. Steven Pearlstein \& Anne Swardson, US, Europe Clash Over Airline Deal, WASH. POST, July 17, 1997 , at $\mathrm{A} 1$.

198. Stevens, supra note 4 , at 275.

199. Guzman, supra note 5 , at 1152 ("It is only necessary to assume that governments and regulators favor their own constituents over foreigners, a reasonable assumption that is present in virtually any model of country behavior."). Sykes emphasizes that national antitrust policy decisions are not in fact made systematically on the basis of careful national welfare calculations. Yet there are enough examples of self-interested national policies and decisions, such as Federal Trade Commission approval of the Boeing/McDonnell Douglas merger, and the European Community challenge to it, to suggest that national policy-makers give more weight to domestic interests than to foreign interests. Alan O. Sykes, Externalities in Open Economy Antitrust and Their Applications for International Competition Policy, 23 HARV. J.L. \& PUB. POL'Y. 89, 92-93 (1999).

200. Fox was criticizing the European approach in the case Aérospatiale Alenia/de Havilland on similar grounds. Eleanor M. Fox, Merger Control in the EEC - Towards a European Merger Jurisprudence, 1991 FORDHAM CORP. L. INST. 738-39 (Barry E. Hawk, ed. 1992).

201. Eleanor M. Fox, Antitrust Regulation Across National Borders, 16 BROOKINGS REV. 30, 30-32 (1998).

202. Kovacic, supra note 197 , at $830-31$.

203. Id. at 872-73.

204. See, e.g., Stevens, supra note 4, at 276 ("President George W. Bush intervened to indicate his support for GE's acquisition of Honeywell, prompting an angry rebuke from Mario Monti that the investigation was 'a matter of law and economics, not politics.'”). Many critics in the United States, including the press, were openly criticizing the European Union specifically the European Commissioner Mario Monti - as biased and protectionist. See Ariana 
believe the European Commission was developing a new antitrust theory for application in this case, or that the theory was a result of a bias against American companies. ${ }^{205}$

Kauper believes that both the Antitrust Division and the Federal Trade Commission have functioned relatively free of interference or influence by other government agencies charged with elements of national economic or industrial policy. "[Due to the] potential influence ... [of] . . . such external pressures on EC decision-making, . . . criticism of the Commission's approach to the Boeing-McDonnell Douglas case as trade policy oriented or more pejoratively, protectionist has at least the ring of plausibility."206 But can national bias ever be proven?

\section{B. Adjudication Versus Legislation}

Can the problem of presumably discriminatory decisions be solved by a system of review by the WTO or by an independent world antitrust forum? ${ }^{207}$ Fox's proposal suggested that a dispute resolution panel could determine, on the basis of the record and with deference to the national court, whether the national law was non-discriminatorily applied. ${ }^{208}$ The solution to different decision-making would, in her opinion, be solved by a consensus on some cosmopolitan principles. ${ }^{209}$ Two of these principles are: (1) Nations should apply their antitrust laws without discrimination based on nationality; and (2) Nations should not allow "national champion" interests to trump competition interests. They should neither enforce nor withhold enforcement in the interests of a national champion. ${ }^{210}$

Eunjung Cha, Microsoft's Euro-Foe: EU's Antitrust Chief Hints He Will Continue Case, WaSH. Post, Nov. 15, 2001, at Financial, E01 ("[he is] trying to use his position to give European companies an advantage over American ones. ... [H]e is more interested in protecting corporate rivals of companies he's investigating than he is in weighing the interests of consumers.").

205. Knowledge@Wharton, Wharton School of the University of Pennsylvania, GE and Honeywell fail to tie the knot, CNET News.com, at http://news.com.com/2009-1017269583.html?legacy=cnet (last modified Jul. 8, 2001) (quoting Edward T. Swaine: "I don't agree with the EC on the substance of its decision, but I can't say I was terribly surprised.").

206. Kauper, supra note 93, at 319.

207. See Fox, supra note 5, at 1135 , reprinted in JACKSON ET AL., supra note 148 (arguing that a free standing World Competition Forum should be created) [hereinafter Fox, Competition Law Reprint]. Recently, Fox seems to have shifted her position to favoring the WTO more; Fox, supra note 41.

208. Fox, Competition Law Reprint, supra note 207, at 1132-33; Fox, supra note 41, at 930. See also Communication from the European Community and Its Member States, WT/WGTCP/W/1 15 (May 25, 1999) (stating that one of the provisions of the WTO agreement would require the enforcement of competition legislation based on nondiscrimination and transparency).

209. Eleanor M. Fox, Competition Law: Linking the World, in TransatlantiC Regulatory CoOperation 243, 250-52 (George A. Bermann et al. eds., 2000).

210. Id. 
Non-discriminatory provisions are important and enforceable in WTO law, and are known as the "most favored nation"211 or "national treatment" provisions. $^{212}$ However, "most favored nation" and "national treatment" apply to generally applicable laws, regulations and requirements, or measures, not to adjudication. ${ }^{213}$ There are two possibilities of discrimination in legislation. If the language of the statute is discriminatory, discrimination can easily be grasped (A must be treated differently than B because he is A and has A features). ${ }^{214}$ The second possibility is to test the consequences of legislation that is indiscriminate on its surface, or develop a measure of whether some people (or goods belonging to some people) are actually being treated differently to others.

The purpose of the national treatment and most favored nation provisions is, thus, to determine whether there is different treatment of domestic and foreign companies. It determines whether there is outright discrimination or a negative effect of the state on foreign producers in comparison to domestic producers, which usually means a reduction of imports as a result of the legislation. $^{215}$ These are the physical events which are "public," may in principle be observed by anyone, and can be "described with reference to any

211. See General Agreement on Tariffs and Trade, Oct. 30, 1947, art I., 61 Stat. A-11, T.I.A.S. 1700, 55 U.N.T.S. 194 [hereinafter GATT].

212. Id. art. III.

213. The principle of national treatment is contained in the GATT, Article III (4), which requires national treatment in respect of all laws, regulations, and requirements affecting the internal sale, offering for sale, purchase, transportation, distribution, or use of goods. It is also found in Article XVII of the General Agreement On Trade In Services, in respect of all measures affecting the supply of services. General Agreement On Trade In Services, Apr. 15, 1994, Marrakesh Agreement Establishing the World Trade Organization [hereinafter WTO Agreement], Annex 1B, art. XVII, 33 I.L.M. 1168 (1994) [hereinafter GATS]. The main provisions in which the principle of "most-favored nation" is found include Article I of the GATT, and Article II of the GATS, where the principle also applies to "measures."

214. This type of discrimination is not hidden in the "private;" it is obvious from the language. Examples of such discrimination in E.U. law include compulsory veterinary inspections on imported (i.e., non-Italian) goods (Case 87/75, Bresciani v. Amministrazione Italiana delle Finanze, 1976 E.C.R 129 (as to Article 25 of the EC Treaty)), having to pay for two roadworthiness tests if your car is bought abroad, (Case 50/85, Bernhard Schloh v. Auto Contrôle Technique, 1986 E.C.R. 1855, (1987) (In this case a violation of Article 28 of the EC Treaty was in question)). Examples from WTO law include a requirement that imported and domestic beef be sold in different stores (Korea-Measures Affecting Imports of Fresh, Chilled and Frozen Beef, WT/DS161, 169 AB/R (Jan. 10, 2001)) and a law establishing a fund used to grant special credit terms for the purchase of domestic agricultural machinery (Italian Discrimination Against Imported Agricultural Machinery, L/833 - 7S/60, at 1 (October 23, 1958).

215. Examples from E.U. law include taxing wine much more heavily than beer by a country which produces a lot of beer and almost no wine, where the United Kingdom was found to be in breach of Article 90 of the EC Treaty (Case 170/78, Commission v. United Kingdom (1983) E.C.R 2265); taxing cars gradually up to a particular power rating, and imposing a high flat-rate for cars above this particular rate, by a country which does not produce cars above this power rating, where a breech of Article 90 of the EC Treaty was again the issue (Case 112/84, Humblot v. Directeur des Services Fiscaux (1985) E.C.R 1367). 
convenient physical framework at any convenient level of description." ${ }^{216}$ The will of the legislator thus transforms itself into an empirically verifiable matter. In legislation, all the consequences of legislation are not legitimate. Discrimination is not a legitimate result.

The goal of decision-making is to reach a decision. All the results of adjudication are legitimate, legal, and put to the decision-maker's disposal if they satisfy the lax standard of not being discretionary. The outcome of adjudication can be a verdict of guilty or not guilty, damages can be awarded or not awarded, a merger can be cleared or not cleared, a corporation may have to pay a fine as a result of anti-competitive behavior or it may not. Frank wrote that when a judge writes an explanation, she writes the apology for her decision. Although she phrases the decision in terms of formal law, she often arrives at her decision before she tries to explain it, and this is where the biases come into play. After the judge has so decided, she writes her "opinion." But, this explanation is often truncated, incomplete, frequently unreal, artificial, distorted, or in a large measure, an afterthought. It omits all mention of many factors that led the judge to decide the case. These opinions are ex post facto or censored expositions. In legal realist terms the decision is made according to will, not reason, whereas the explanation of the decision is made according to reason. ${ }^{217}$ The discriminatory decision is, thus, in the will that cannot be penetrated; it remains in the sphere of the "private." 218 Only the aforementioned legitimate outcomes of adjudication are physical events, which are public in that they may be observed by anyone, although in a relative sense.

Discretion of adjudicatory bodies can, to some extent, be judged ex post facto. In American jurisprudence, the prevalent test is "arbitrary and capricious, an abuse of discretion, or otherwise not in accordance with law."219 In French jurisprudence, the prevalent test is "détournement des pouvoirs" or "abuse of right.",220 As an illustration, there has been a frequent problem in antidumping cases regarding how much deference a panel should give to the decision of a national antidumping authority that material injury to domestic industry was demonstrated by the presented facts. ${ }^{221}$ The WTO Anti-dumping Agreement provides that in its assessments of the facts, the panel shall determine whether the national anti-dumping authority's evaluation of the facts

216. David Hodgson, The Mind Matters: Consciousness and Choice in a Quantum WORLD 55 (Oxford University Press 1991).

217. Jerome Frank, What Courts Do In Fact, 26 IL. L. Rev. 645, 653 (1932); see also anthony T. Kronman, The Lost Lawyer: Falling Ideas of the Legal Profession 196 (1993).

218. HodgSON, supra note 216 , at 54-55 (arguing that mental events are private to the subject involved and impenetrable even if a machine capable of 'decoding' patterns of a person's brain activity is invented).

219. 5 U.S.C.A. § 706(2)(D); see also JACKSON ET AL., supra note 148, at 113-14.

220. L. NeViLle Brown ET. Al., French Administrative LaW 229 (Oxford University Press 4th ed. 1993).

221. JACKSON ET AL., supra note 148 , at 289-90. 
was unbiased and objective. If the evaluation was unbiased and proper, even though the panel might have reached a different conclusion, the evaluation will not be overturned. ${ }^{22}$ All of these can be used only to prove the most egregious forms of discrimination. If the false motivation behind the decision cannot be discerned from the reasoned ex post facto explanation, the decision will be deemed correct.

It can thus be shown for example that only Japanese people are affected by the legislative act. However, it may be very difficult to prove that a particular Japanese person was convicted because he was Japanese, ${ }^{223}$ or that a particular merger was blocked because two Japanese companies decided to merge, unless this is patently obvious from the reasoned decision. National bias and discrimination are hidden in the logical ex post facto explanation and are not able to be articulated. It could not be proven that the FTC or European Commission decisions in the $G E / H o n e y w e l l$ and Boeing/MCD cases were arbitrary and capricious. Thus, a nondiscrimination standard, as proposed by Fox, cannot effectively grasp and alleviate the discriminatory application of laws. Given the legal realist description of decision-making, none of the above standards will solve the problem of different or biased decision-making in the WTO, or in any other international organization.

Furthermore, Fox's proposal provides for a reviewing body to examine only whether laws are non-discriminatorily applied, without resolving facts. ${ }^{24}$ However, the distinction between norms and facts in this context may not prove to be useful. According to Frank, a judge needs to find the law and define the case to which she must apply it. These tasks require a number of controversial choices. She chooses the norm according to a prior decision regarding which facts she will use in decision-making, causing other facts of the case to be excluded in the process. She justifies the choice of the norm with the facts chosen. She then goes back from the norm to the facts and makes another choice, and so on. 225

A valid analysis trying to review non-discriminatory application of laws to a particular set of facts could not ignore facts. The norm is chosen according to facts, and facts determine the meaning of the norm. ${ }^{226}$ Given the difficulties

222. Agreement on Implementation of Article VI of the General Agreement on Tariffs and Trade, Apr. 15, 1994, Marrakesh Agreement Establishing the World Trade Organization, Annex 1C, art. 17.6(ii), 1868 U.N.T.S. 201.

223. Compare Furman v. Georgia, 408 U.S. 238, 253 (1972) ("We cannot say from facts disclosed in these records that these defendants were sentenced to death because they were black.") (5-4 decision, Douglas J., concurring). Similarly, the German Federal Constitutional Court's Schumman formula would also not be of help as it entails a thorough constitutional review. Nor can the formula grasp the one-time discriminatory attitude of the decision-maker as described above.

224. Fox, Competition Law Reprint, supra note 207, at 1133.

225. See Frank, supra note 217, at 653-656.

226. For the relativity of the separation of facts and norms, see UNGER, supra note 37 at 32 .

If there are no intelligible essences, there is no predetermined classification of the world .... In other words, a fact becomes what it is for us because of the way 
of allocating decision-making authority between agencies and courts, and the complications this standard is causing even on the national level, ${ }^{227}$ where the competence of the reviewing body is not problematic as to the question of supranationalism, this standard cannot provide a useful standard of review. In practice, it could not work without giving explicit law-making powers to the reviewing body. ${ }^{228}$

Moreover, this decision-making process is a fortiori even more problematic in the case of merger review. The facts a decision-maker applies to the norm are not past events, but rather products of a theory of future behavior the decision-maker chooses to use, and these facts are uncertain events. Merger review deals with probabilities, not certainties, ${ }^{229}$ which makes it even more susceptible to discretion, and thus to political and national bias.

The claim of national bias cannot be articulated, whether it is a product of state pressure, ${ }^{230}$ or the unconscious. ${ }^{231}$ Therefore, challenging court decisions on the grounds of bias is next to impossible. A reasoned decision cannot be crushed. Falk argues that the presentation of why one decides a case the way one does is premised on the professional code of discourse that deliberately tries to disguise that bias in the context of justification. Thus, one is up against a kind of impediment that can never really be addressed. ${ }^{232}$ Therefore, any standards of review are appropriate for evaluating the bias of regulatory bodies or courts, and will not be able to deal with the problem of discriminatory decisions.

we categorize it. How we classify it depends on the categories available to us in the language we speak, or in the theory we use, and on our ability to replenish the fund of categories on our disposal.

Id.

227. See, e.g., Alfred C. Aman, JR. \& William T. MAYton, Administrattve LaW 449-60 (2d ed. 2001).

228. See infra Part III. E.

229. See Ross, supra note 119.

230. Slaughter, Liberal International Relations Theory and International Economic Law, supra note 7, at 738 ("[R]eliance on a foreign sovereign's claim of interest in a specific case may reflect nothing more than an individual litigant's ability to pressure the Foreign Office, a relatively costless benefit a government can provide to its citizens on a case by case basis.").

231. Holmes, supra note 8, at 465-66 ("The language of decision-making is mainly the language of logic .... Behind the logical form lies a judgment as to the relative worth and importance of competing legislative grounds, often an inarticulate and unconscious judgment, it is true, and yet the very root and nerve of the whole proceeding.").

232. See Richard Falk, The Independence and Impartiality of International Judges, 83 AM. SOC'Y INT'L L. PROC. 508, 517 (1989); see also FRIEDRICH NIETZSCHE, THE WILL TO POWER, 151 (Walter Kaufmann \& R. J. Hollingdale trans., Vintage Books 2d. ed.1968) (1901).

The necessity of false values. - One can refute a judgment by proving its conditionality: the need to retain it is not thereby removed. False values cannot be eradicated by reasons any more than astigmatism in the eyes of an invalid. One must grasp the need for their existence: they are a consequence of causes which have nothing to do with reasons.

Id. 


\section{Economic and Efficiency Approach - Can National Bias be Alleviated?}

Fox argues that politics should be left out of antitrust and that the efficiency standard alone should be taken into account. ${ }^{233}$ However, economic analysis is prone to ideology and bias just as well. According to Duncan Kennedy, efficiency is not an apolitical, distributively-neutral criterion, or one in which there is no place for political decision-making. ${ }^{234}$ An older stance is that efficiencies are very difficult to prove. ${ }^{235}$ Today, the whole efficiency analysis is built on likelihood in the same way as the rest of the merger review. ${ }^{236}$ Lande and Langenfeld maintain that since merger analysis has moved from reliance on surrogates towards unilateral anticompetitive effects, the application of econometric analysis of market data, and game-theory based simulation programs, there "does not appear to be an ideological bias involved in the government's new methodology." ${ }^{, 237}$ Nevertheless, as they show, there are problems with obtaining necessary data in a form that is of sufficient quality. Furthermore, how economic theories are applied to a particular set of facts is crucial. ${ }^{238}$ For example, consider how the borderline between the efficiency "offense" and efficiency "defense" is drawn, or what evidence is needed to support a particular case for buyer power. ${ }^{239}$ The outcome depends on which economic theories you use and, essentially, which evidence is given more weight.

Predictions on the future are a key and inherent part of merger review, ${ }^{240}$ thus the scope for manipulation is non-negligible. One can ex post facto justify a decision in one way or the other. There is no neutral economic baseline to replace an impossible neutral legal baseline. ${ }^{241}$ Economic or "un-ideological"

233. Eleanor M. Fox, Lessons From Boeing: A Modest Proposal to Keep Politics Out of Antitrust, ANTTTRUST REP., Nov. 1997, at 19.

234. KENNEDY, supra note 74, at 288.

235. See, e.g., David T. Scheffman, Merger Policy And Enforcement At The Federal Trade Commission: The Economist's View, 54 ANTITRUST L.J. 1, 117, 120 (1985).

Efficiencies have been the most difficult thing to get really convincing evidence on, because you are dealing there with a very speculative thing: What will happen after the merger?... [I]n GM-Toyota we spent a great deal of time on analyzing the potential for efficiencies. It is a very difficult issue to get at ....

Id.

236. See Ross, supra note 119.

237. Robert H. Lande \& James Langenfeld, From The Surrogates To Stories: The Evolution of Federal Merger Policy, 11 ANTTTRUST 5, 7 (1997).

238. See, e.g., INTERNATIONAL CHAMBER OF COMMERCE, COMMISSION ON COMPETTTION, COMMENTS ON EUROPEAN COMMISSION DRAFT NOTICE ON THE APPRAISAL OF HORIZONTAL MERGERS, http://www.iccwbo.org/home/statements_rules/statements/2003/ec_draft_horizontal_ mergers.asp (Apr. 30, 2003).

239. See, e.g., Press Release, Europa, Commission Adopts Comprehensive Reform of EU Merger Control (Dec. 11, 2002), http://europa.eu.int/rapid/start/cgi/guesten.ksh?p_action. gettxt=gt\&doc=IP/02/1856l0|RAPID\&lg=EN (last visited Nov. 19, 2004).

240. See Fiebig, supra note 11, at 237 ("Merger control laws are generally preventative in nature, i.e. they seek to prevent a structural restraint of competition prior to its occurrence.").

241. KENNEDY, supra note 74, at 288. 
assumptions will, therefore, in no circumstance, overcome the problem of national bias.

\section{A Lesson From International Commercial Arbitration}

As has been discussed, foreign parties do not trust domestic courts. They sometimes fear that the courts of the other contracting party's state will favor its own nationals or be subservient to national interests. ${ }^{242}$ A survey conducted among international commercial arbitration specialists on the relevance of specific factors in decisions to use this dispute resolution method revealed that neutrality/impartiality is the most relevant reason, followed by the existence of treaties, ensuring enforcement of the award. ${ }^{243}$ "Two values are central to the decision-making process: impartiality (neutrality) and balance (equal procedural chances offered to both sides), "244 both of which can be offered by arbitration as opposed to domestic courts. The results of the survey may be explained by distrust of "the others:" "When different outcomes occur within the U.S. system, this phenomenon is not regarded as illegitimate; it is a fact of life in an open and evolving system. But when a foreign enforcer stops a merger of U.S.-based firms, there are cries of illegitimacy."245

Jung offers a psychological explanation. He claims that human iniquity stems from the great universal misperception that people are merely what their consciousness knows of themselves. This is why they regard themselves as harmless. They do not deny that terrible things have happened and still go on happening, but believe that it is always "the others" who do them. ${ }^{246}$ Nevertheless, a factor of national bias in decision-making cannot be excluded. It is not necessarily a consequence of an external pressure by interest groups, but that the world is judged according to how individuals perceive themselves, based on their (collective) ${ }^{247}$ identity. ${ }^{248}$ The judge therefore loses her role as

242. See, e.g., W. Laurence Craig, Some Trends and Developments in the Laws and Practice of International Commercial Arbitration; 30 TEX. INT'L L.J. 1, 2-3 (1995) ("Parties seek to avoid these forums for fear that they will be at a disadvantage due to unfamiliarity with the jurisdiction's language and procedures, preferences of the judge, and possibly even national bias.").

243. See Tibor VÁrady, John J. Barceló III \& ARTHUR T. Von MEHREn, INTERNATIONAL. COMMERCIAL ARBITRATION 395, 396 (1999) (stating that seventy-two percent said that the former and sixty-four percent that the latter reason is highly relevant).

244. Id. at 26.

245. Fox, supra note 96, at 476; see also Tarullo, supra note 5, at 497 ("Even a good-faith, consistent application of existing doctrine to a particular transaction or practice of foreign companies might be perceived by the foreign country as hostile, no matter what its own competition enforcers may explain about the other country's law.").

246. Carl Gustav Jung, The Undiscovered Self 67 (2002).

247. Smith claims that nations-and national identity-are formed on a definite historic territory, a common economy, with territorial mobility throughout, a shared public, mass education-based culture, and common legal rights and duties for all members. Anthony D. Smith, The Formation of National Identity, in IDENTTTY 129, 135 (Henry Harris ed., 1995).

248. See Jonathan Glover, The PhILosophy and Psychology of PERsonal IDENTITY 
an impartial observer in a process and can identify herself with one of the parties. "The struggle between independence and partiality is particularly evident among judges in international tribunals" and "affects members of most non-plenary treaty organs. ${ }^{249}$

In the International Court of Justice (ICJ), for example, an empirical study reveals that judges of the ICJ, whose country is a litigant, vote more frequently in their country's favor. ${ }^{250}$ For these reasons, international commercial arbitration is flourishing in disputes between individuals of liberal states, ${ }^{251}$ where courts are, as Slaughter claims, supposed to be impartial. ${ }^{252}$ Concerns of national bias arise in countries where the judiciary is relatively independent.

Many dispute-resolution systems ${ }^{253}$ have acknowledged the problem of national bias and the futility of detecting it. These systems attempt to avoid bias by employing a special composition of international bodies. The implementation of these bodies is the closest countries have come to eliminating the problem of national bias.

154 (1988) (suggesting that there are "links between our outlook and our conception of ourselves").

249. William J. Aceves, Critical Jurisprudence and International Legal Scholarship: A Study Of Equitable Distribution, 39 ColUM. J. TRANSNAT'L L. 299, 344 (2001).

250. See John P. Gaffney, Due Process In The World Trade Organization: The Need For Procedural Justice in the Dispute Settlement System, 14 AM. U. INT'L L. REV. 1173, 1201-02 (1999); see also Edith Brown Weiss, Judicial Independence and Impartiality: A Preliminary Inquiry, in The INTERNational Court of Justice at A Crossroads 123, 126 (Lori Fisler Damrosch ed., 1987).

251. See, e.g., Kenneth R. Davis, Unconventional Wisdom: A New Look at Articles V and VII of the Convention on the Recognition and Enforcement of Foreign Arbitral Awards, 37 TEx. INT'L L.J. 43, 87 (2002) (noting that "more and more multinational businesses turn to arbitration to resolve commercial disputes").

252. For Slaughter's divergent opinion on international commercial arbitration see Slaughter, A Global Community of Courts, supra note 7, at 204.

Such battles have long been the subject of private international law, and have also fueled the growth of international commercial arbitration. Today, however, the question facing judges around the world, in the words of Judge, now Justice, Breyer, is how to 'help the world's legal systems work together, in harmony, rather than at cross purposes.'

Id. Compare Anne-Marie Slaughter, Judicial Globalization, 40 VA. J. INT'L L. 1103, 1112 (2000).

Such battles have long been the stuff of private international law; they have also fueled the growth of international commercial arbitration.... What is new is the rise of a distinct and meaningful concept of 'judicial comity,' deference not to foreign law or foreign national interests, but specifically to foreign courts.

Id.

253. Including the International Court of Justice, where, ironically, it is a judge's partiality to his or her personal, intellectual, and legal development that brings legitimacy to the tribunal. See Thomas M. Franck, The Structure of ImPartlality: EXamining the RIDDle of ONE LAW IN A FRAGMENTED WORd 289 (1968). See, e.g., Lucille M. Ponte \& Erika M. Brown, Resolving Information Technology Disputes After NAFTA: A Practical Comparison of Domestic and International Arbitration, 7 TUL. J. INT'L \& COMP. L. 43, 59 (1999) (explaining that in NAFTA, for instance, in the selection of arbitrators, the "parties may decide to select 


\section{E. Unification Within an International Organization}

If the problem of different decisions cannot be effectively solved by nondiscrimination clauses, cooperation, or positive comity, can a national authority's decision be struck out at the level of international law on the grounds that its interpretation of international agreements was impermissible, ${ }^{254}$ or that it failed to properly enforce them? ? $^{25}$

The Sherman and Clayton Act, as well as Articles 81 and 82 of the Treaty of Rome, have always been models for an indeterminate legal norm, ${ }^{256}$ the fleshing out of this skeleton being left to the federal courts ${ }^{257}$ or administrative agencies. Competition policy depends on experienced enforcers and judges who apply general statutes appropriately in complicated and differing market circumstances. $^{258}$ It developed to a large extent through court activism. ${ }^{259}$ The crucial role of the decision-maker, and the legal system in which he or she is operating, can also be seen in the institution of quantitative restrictions and measures with equivalent effect, as this is an institution of both the European Union and WTO law. This jurisprudence clearly shows the difference between a supranational and international organization.

The Treaty Establishing the European Community (EC Treaty) and the General Agreement on Tariffs and Trade (GATT) share similar provisions and fundamental features. ${ }^{260}$ Pierre Pescatore notes that "the draftsmen of the EEC Treaty have summarized with continental succinctness what the GATT expresses with Anglo-Saxon discursiveness."261 Indeed, the wording of the prohibition of quantitative restrictions and measures having equivalent effect is very similar. Compare Article 28 of the EC Treaty with Article XI.1 of GATT:

Article 28. of the EC Treaty:

Quantitative restrictions on imports and all measures having equivalent effect shall be prohibited between Member States.

Article XI.1 GATT:

No prohibitions or restrictions other than duties, taxes or other

arbitrators that equally reflect the backgrounds of each of the participants or choose arbitrators from other unrelated countries").

254. Compare supra note 222 and accompanying text.

255. Tarullo, supra note 5 , at 492.

256. See Kauper, supra note 93, at 310 . For Article 81 of the EC Treaty see generally Paul Craig \& Gráinne de Búrca, EU law, Text, Cases \& Materials 938, 962 (Oxford University Press 3d ed. 2003).

257. Kauper, supra note 93, at 310.

258. Tarullo, supra note 5 , at 490.

259. See generally BORK, supra note 105 , at $72-89$.

260. PIERRE PESCATORE, INTRODUCTION TO THE EUROPEAN COMMUNITY AND GATT XVXVII (Meinhard Hilf et al. eds., 1986).

261. Id. at XV. 
charges, whether made effective through quotas, import or export licenses or other measures, shell be instituted or maintained by any contracting party on the importation of any product of the territory of any other contracting party....

The language of the exceptions in Article 30 of the EC Treaty, and of Article XX of the GATT, is even more similar. ${ }^{262}$ Law in action, however, is in many important respects quite different. Article 28 of the EC Treaty has been interpreted very broadly by the European Court of Justice (ECJ). In the Dassonville case, the Court held that "all trading rules enacted by Member States which are capable of hindering, directly or indirectly, actually or potentially, intra-Community trade" are forbidden. ${ }^{263}$ Interpretation of Article XI of the GATT is also quite broad, ${ }^{264}$ but not as broad as the Dassonville decision. The dispute settlement body has ruled that legislation requiring a competent body to act in violation of the GATT violates the Agreement, even though there has been no opportunity to implement such a requirement. On the other hand, however, legislation merely giving authorities the power to act in violation of the GATT is, unlike following Dassonville in E.U. law, in itself not inconsistent with the General Agreement. ${ }^{265}$

In decisions such as the famous Cassis de Dijon case, ${ }^{266}$ the ECJ has tremendously developed E.U. law. Elimination of discriminatory barriers to trade, which was also to some extent achieved by the WTO, is a necessary condition for a common market, but it is not sufficient. There are many rules

262. See EC TREATY; GATT, supra note 211.

263. Case 8/74, Procureur du Roi v. Dassonville, 1974 E.C.R. 837.

264. See, e.g., Japan - Trade in Semi-Conductors, L6309 - 35S/116 (May 4, 1988) (stating that Article XI:1, unlike other provisions of the General Agreement, does not refer to laws or regulations but more broadly to measures, which indicates clearly that any measure instituted or maintained by a contracting party that restricts the exportation or sale for export of products is covered by this provision, irrespective of the legal status of the measure).

265. See GATT Dispute Panel Report on United States Restrictions on Imports of Tuna, 30 I.L.M. 1594, 33-34 (1991) (not adopted), available at http://www.worldtradelaw.net/reports/ gattpanels/tunadolphinI.pdf (Sept. 3, 1991). The American statute authorized the competent body to extend the prohibition of importation of tuna to other products. The question raised was whether mere authorization of the statute to act inconsistently with Article XI of GATT constituted, in itself, a measure in conflict with the GATT. See id. Although not overruling this decision, the decision on Section 301 of the U.S. Trade Act of 1974, as to Article XXIII of GATT, clearly shows a different trend. Panel Report, Section 301: United States - Sections 301-310 of the Trade Act of 1974 WT/DS152/R (Dec. 22, 1999) (adopted Jan. 27, 2000), available at http://www.sice.oas.org/DISPUTE/wto/tract01e.asp [hereinafter WTO Decision on the U.S. Trade Act]. "In treaties which concern only the relations between states, state responsibility is incurred only when an actual violation takes place. By contrast, in a treaty the benefits of which depend in part on the activity of individual operators [sic] the legislation itself may be construed as a breach, since the mere existence of legislation could have an appreciable 'chilling effect' on the economic activities of individuals." Id. at para. 7.81; see Trade Act, Pub. L. No. 93-618, §§ 301-10 (1974) (codified at 19 U.S.C. §§ 2411-2420).

266. Case 120/78, Rewe-Zentral AG v. Bundesmonopolverwaltung fuir Branntwein (Cassis de Dijon), 1979 E.C.R. 649. 
that, on their face, do not discriminate between products from different countries, but can nonetheless be an obstacle to the free movement of goods. ${ }^{267}$ In Cassis de Dijon, the ECJ ruled that if a particular good can legally be sold in one member state, it can also be sold in other member states, unless a mandatory requirement can be invoked. ${ }^{268}$ WTO dispute settlement bodies were unable to achieve such a far-reaching result.

Ensuing "post-Cassis" ${ }^{269}$ cases of the ECJ, and cases such as Cinétheque, Torfaen, and $\mathrm{Keck}^{270}$ are therefore also unthinkable in the WTO system. Competition policy, which Wesseling describes as positive integration, developed simultaneously with negative integration, ${ }^{271}$ and not in isolation from other developments in E.U. law. It was informed by developments taking place in related legal, political, and economic community fields. ${ }^{272}$ The developing common market required a common regulatory policy. ${ }^{273}$ Negative integration (free trade) and positive integration (antitrust regulation) therefore go hand-inhand, and the latter cannot overcome the former. In other words, discourse on international integration of competition policy cannot go much further than discourse on free trade. ${ }^{274}$ WTO jurisprudence on quantitative restrictions shows the limits in comparison with the jurisprudence of the ECJ.

The WTO is an organization of public international law, a specialized agency of the United Nations under Article 57 of the Charter of the United

267. CRAIG \& De BúRCA, supra note 256, at 636.

268. See id. at 638.

269. Id. at $639-40$.

270. Case 61/84, Cinétheque v. Fédération Nationale des Cinémas Français, 1985 E.C.R. 2605; Case 145/88, Torfaen v. B\&Q 1989 E.C.R. 3851; Case 268/91, Criminal Proceedings against Keck and Mithouard 1993 E.C.R. I-6097. All three cases deal with limits to the Cassis jurisprudence regarding the selling arrangements, and conditions on which all goods were sold. See generally CRAIG \& DE BúRCA, supra note 256, at 641-58.

271. Wesseling defines positive integration as the "positive" regulatory nules of the market, such as antitrust, as opposed to the negative integration, which refers to measures which advance market integration by eliminating barriers and promote free flow of goods, services, capital and labor. REIN WESSELING, THE MODERNIZATION OF EC ANTTTRUST LAW 59-60 (2000).

272. Id. at 51 .

273. Both are dynamically connected-common market requires competition policy and one of the goals of EC competition law is the creation of a single market. See CRAIG \& DE BÚRCA, supra note 256, at 936-37; Lee McGowan \& Stephen Wilks, The First Supranational Policy in the European Union: Competition Policy, 28 EUR. J. POL. RES. 141, 141 (1995) (arguing that competition policy has not constituted an end in itself, but rather the central means towards the fundamental goals laid down in the Rome Treaty: the establishment of the internal market, the approximation of economic policy, the promotion of harmonious development between the member states, economic expansion, and a higher standard of living for consumers).

274. This is not to say that some regulatory cooperation should not be present in areas such as environment, irrespective of whether there is any free trade cooperation. It is to say, however, that an institution which does not have as much power on negative integration as the ECJ or the European Commission will also not be as powerful with regard to positive integration. The distinction between positive and negative integration itself is artificial. Compare WESSELING, supra note 271, at 32 . The distinction could also be challenged on the legal realist rejection of the difference between rules of intervention and non-intervention. Compare KENNEDY, supra note 34 and accompanying text. 
Nations. ${ }^{275}$ It is not a supranational organization such as the European Union, ${ }^{276}$ which allows the ECJ, as "chief architect" ${ }^{\text {277 }}$ of E.U. law, far greater leeway in deciding cases, and determining the rights and obligations of states. The ECJ may also decide on the rights and obligations of individuals. This is probably one of the reasons behind the Understanding of the Rules and Procedures Governing the Settlement of Disputes provision. This provision states that members recognize that the WTO dispute settlement system serves the rights and obligations of members under the covered agreements and clarifies the existing provisions of those agreements in accordance with customary rules of interpretation of public international law.

"Recommendations and rulings of the Dispute Settlement Body (DSB) cannot add to or diminish the rights and obligations provided for in the covered agreements." 278 This rule is questionable under all jurisprudential rules, with the exception of Langdellian formalists or Montesquieu's description of judges, as the mouth that pronounces the words of the law. ${ }^{279}$ Duncan Kennedy distinguishes between five leading theories of adjudication typologies: Hart's (deduction + judicial legislation); Unger's (judicial legislation); Raz's (deduction + limiting rules + judicial legislation); MacCormick's (deduction + coherence + judicial legislation); Dworkin's (deduction + coherence + personal political theory); and Civilians' (deduction + coherence). ${ }^{280}$ None of these would argue that in "hard cases" a decision-maker does not add to or diminish the rights and obligations provided for in the statute or agreement. ${ }^{281}$

\section{U.N. CHARTER art. 57.}

276. See, e.g., Laurence R. Helfer \& Anne-Marie Slaughter, Toward a Theory of Effective Supranational Adjudication, 107 YALE L.J. 273, 287-88 (1997).

The term 'supranational' . . . is typically used to identify a particular type of international organization that is empowered to exercise directly some of the functions otherwise reserved to states. The distinguishing feature . . . is the greater transfer of or limitation on state sovereignty involved in the establishment of a supranational organization. ... . More precise definitions of supranational organizations emphasize their ability to penetrate the surface of the state.

Id.

277. Hualte Rasmussen, On Law and Policy in the EuRopean Court of Justice: A Comparative Study In Judicial. Policy Making 3 (1986).

278. Understanding on Rules and Procedures Governing the Settlement of Disputes, Apr. 15, 1994, WTO Agreement, http://www.wto.org/english/docs_e/legal_e/28-dsu.pdf. [hereinafter Understanding on Dispute Settlement].

279. Charles De Secondat, Baron De Montesquieu, The Spirit of the Laws, bk XI, ch 6 at 163 (Anne M. Cohler et al. eds. \& trans., Cambridge University Press 1989) (1748).

280. KENNEDY, supra note 74 , at 37.

281. Dworkin, for example, argues that the judge discovers rights and does not invent new rights retrospectively. See RONALD DWORKIN, TAKING RIGHTS SERIOUSLY 81-100 (1977). This, however, does not mean the judge discovers the rights which are explicitly provided in the statute. 
In WTO law, the rights of non-parties to make amicus submissions, ${ }^{282}$ that a member state is limited in prescribing environmental standards for the goods sold on its territory ${ }^{283}$ or that a member state bears responsibility for acts of all departments of government, including its judiciary, ${ }^{284}$ are just some of the examples of rights and obligations definitely not provided for in the covered agreements. It is difficult to determine the exact impact of this norm on constraining dispute settlement bodies. Though its goal could not possibly be achieved in full, this norm may have contributed to the more restraining system and nature of WTO law, which makes the argument of fit ${ }^{285}$ quite different from the one in E.U. law.

This analysis shows that the same norm works differently in different institutions and legal systems. ${ }^{286}$ Two conclusions can therefore be drawn. First, paper rules in international organizations should not be created if they are not able to achieve the desired result. Second, if a norm works differently in different adjudicatory institutions, ${ }^{287}$ which all add to or diminish rights and obligations at least in "hard cases," then at minimum adjudicatory institutions do have an independent impact. ${ }^{288}$ International law is thus by no means epiphenomenal. In the above categorization ${ }^{289}$ (which leaves out formalists), any addition to deduction proves that any international adjudicatory body has an independent impact, at least in hard cases.

A further emanation of the public international law nature of the WTO is its lax standards of review. WTO law would not be able to unify different (doctrinal) approaches. The WTO Antidumping Agreement provides that where the panel finds that a relevant provision of the Agreement admits more than one permissible interpretation, it shall find the authorities' measure to be in conformity with the Agreement if it rests upon one of these permissible interpretations. ${ }^{290}$ This is similar to Article 11 of the Dispute Settlement Understanding, ${ }^{291}$ not a total deference to the findings of the national

282. See GATT Secretariat, United States - Import Prohibition of Certain Shrimp and Shrimp Products, WT/DS58/AB/RW (Nov. 21, 2001) [hereinafter U.S. Shrimp Products]. See also JACKSON ET AL., supra note 148, at 316-17.

283. See generally U.S. Shrimp Products, supra note 282.

284. Id. at para. 173.

285. DwORKIN, supra note 104.

286. Compare Tarullo, supra note 5, at 486. Thus, it is essential which organization, or forum, makes the decision. Contra Slaughter, A Global Community of Courts, supra note 7, at 209 ("As choice of law principles converge, the particular forum in which a dispute is heard will become increasingly irrelevant.").

287. Compare Tarullo, supra note 5, at 486. For Dworkin's argument of fit, see DwORKIN, supra note 104.

288. Compare John. J. Mearsheimer, The False Promise of International Institutions, 19 INT'L SEC. 5, at 7, 8, 11 (1995).

289. KENNEDY, supra note 74, at 37.

290. See Agreement on Implementation of Article VI of the General Agreement on Tariffs and Trade, Apr. 15, 1994, Marrakesh Agreement Establishing the World Trade Organization, Annex 1A, art. 17.6(ii), 1868 U.N.T.S. 201.

291. Understanding on Dispute Settlement, supra note 278. 
authorities, but it is not a de novo review either. ${ }^{292}$

A harsher standard is in place as far as the Agreement on Safeguards is concerned. A panel must find that an explanation is not adequate if an alternative explanation of the facts is plausible and the competent authorities' explanation does not seem adequate in the light of that alternative explanation. ${ }^{293}$ Nevertheless, an important difference must be noted. In the case of safeguard measures, the issue in dispute is a member state's decision to apply safeguard measures against other member states. A panel's action concerns settlement of disputes between members regarding their rights and obligations under WTO law. ${ }^{294}$

In antidumping, the panel is, although in a dispute between member states, dealing with a member state's decision on the actions of individuals. ${ }^{295}$ Unlike in E.U. law, individuals are not subjects of WTO law. ${ }^{296}$ Nonetheless, if private parties are permitted to interfere with free market forces, and to restrain trade between countries, a concern has been raised that they may effectively replace the government-imposed barriers to trade that the WTO system is supposed to meet. ${ }^{297}$ There have been suggestions that the WTO should deal with the actions of individuals. Nevertheless, serious ones ${ }^{298}$ do not depart, to a large degree, from the established doctrine that the WTO Agreement, and specifically Article XI of the GATT, refers only to policies or actions of governments, and does not cover those of private parties. ${ }^{299}$

The decision to adopt antitrust laws, a particular type of antitrust law, as well as their enforcement go to the heart of a state's constitutional system. ${ }^{300}$

292. Compare GATT Secretariat, EC Measures Concerning Meat and Meat Products (Hormones) WT/DS26 \& 48AB/R (Appellate Body Report, February 13, 1998), para. 117.

293. GATT Secretariat, United States - Safeguard Measures on Imports of Fresh, Chilled or Frozen Lamb Meat from New Zealand and Australia, WT/DS177 \& 178/AB/R (May 16, 2001), para. 106.

294. Understanding on Dispute Settlement, supra note 278, at art. 1(1).

295. JACKSON ET AL., supra note 148, at 696 (noting that the GATT does not forbid dumping since companies, not governments, dump).

296. WTO Decision on the U.S. Trade Act, supra note 265, at para. 7.72; see GIUSEPPE SChIAVONE, INTERnATIONAL ORganizations: A DictionaRy DiRECTORY 3 (3d ed. 1993) ("Supranational organizations have the ability to make decisions which are directly binding upon member states, public and private enterprises, as well as individuals within these states, whereas traditional international organizations can act or execute decisions only by or through member states.").

297. JACKSON ET AL., supra note 148, at 1110.

298. See, e.g., Tarullo, supra note 5, at 503 (stating that the WTO should deal with "import barriers that arise because of governmental and private actions that, for historical or regulatory reasons, are essentially inextricable").

299. GATT Dispute Panel Report on Argentina - Measures Affecting the Export of Bovine Hides and the Import of Finished Leather, WT/DS155/10 (Aug. 31, 2001); GATT Dispute Panel Report on Japan - Measures Affecting Consumer Photographic Film and Paper, WT/DS44/R (Apr. 22, 1998) ("There is no obligation of the Member States to exclude the possibility that state measures would enable private parties to directly or indirectly obstruct trade, if state measures by themselves do not obstruct trade.").

300. The U.S. Supreme Court, for example, believes that "antitrust laws . . . are as 
The role of courts in society has been one of the key questions of antitrust law. ${ }^{301}$.The role of unelected judges is already problematic at the national level. $^{302}$ Giving decision-making power to the New Prince ${ }^{303}$ is a fortiori more problematic at the international level, as it involves the question of the loss of sovereignty. ${ }^{304}$ An organization with a low level of accountability, legitimacy, and transparency, such as the WTO, ${ }^{305}$ cannot play the role of governing the behavior of private parties. Involvement of competition policy in the WTO would by itself not change the WTO's legitimacy, ${ }^{306}$ rather the structure and substantive and procedural law would. Any supranational powers as developed in the European Community ${ }^{307}$ are therefore out of the question.

An effective de novo review of national authorities' decisions would de facto entail conferring obligations on individuals. By effectively reviewing national antitrust authorities' decisions on the actions of individuals, the WTO would decide on an individual's obligations and not merely on government violations of international agreements on proper enforcement. ${ }^{308}$ This would be a quantum leap in the WTO's approach to individuals. The problems it poses

important to the preservation of economic freedom and our free enterprise system as the Bill of Rights is to the protection of our fundamental freedoms." United States v. Topco, 405 U.S. 596, 610 (1972).

301. See, e.g., BoRK, supra note 105 , at 16 (arguing that antitrust history should constitute a warning about the adjudicative process and the danger of relying upon courts to evolve major social policy).

302. See, e.g., Mark V. Tushnet, Following the Rules Laid Down: A Critique of Interpretivism and Neutral Principles, 96 HARV. L. REV. 731, 805-24 (1983).

303. Compare Frank 1. Michelman, Bush v. Gore: Suspicion, or the New Prince, $68 \mathrm{U}$. CHI. L. REv. 679 (2001).

304. The International Competition Network also recognized the realities of the polycentric organization of the competition world. One of its guiding principles is the principle of sovereignty. William J. Kolasky, Address at the International Bar Association Sixth Competition Conference, http://www.usdoj.gov/atr/public/speeches/200234.pdf (Sept. 20, 2002); see also Klein, supra note 19.

305. See Giandomenico Majone, International Regulatory Cooperation: A NeoInstitutionalist Approach, in TRANSATLANTIC REGULATORY COOPERATION 119, 143 (George A. Bermann et al. eds., 2000) ("The delegation of policy-making powers to politically independent, or non-majoritarian, institutions immediately raises the issue of democratic accountability."). For WTO's legitimacy, see Ralph Nader \& Lori Wallach, GATT, NAFTA, and the Subversion of the Democratic Process, in The CaSe Against THE Global Economy 92 (Jerry Mander \& Edward Goldsmith eds., 1996); Tarullo, supra note 5, at 494. For WTO's transparency, see JACKSON ET AL., supra note 148 , at 316.

306. Contra Ernst-Ulrich Petersman, Globalization and Transatlantic Regulatory Cooperation: Proposals for EU-US Initiatives to Further Constitutionalize International Law, in TRANSATLANTIC REgUlatory COOPERATION 615, 620 (George A. Bermann et al. eds., 2000) ("The traditional focus of competition policy on general consumer welfare, individual rights, and judicial protection would enhance the democratic legitimacy of WTO law and its political acceptance by "civil society.").

307. See Council Regulation 17, 1962 O.J. 13 (204) 1 (setting out the European Commission's supranational powers, which are essential for the existence of the common competition policy); NichOLAS MOUSSIS, GUIDE TO EUROPEAN POLICIES 229 (2002).

308. Cf. Tarullo, supra note 5, at 490 (the adjudicatory role of "WTO dispute settlement panels would require a more or less explicit delegation of lawmaking' authority to those panels ...."). 
are that it would be introduced by stealth, and that the concept of individuals as subjects is, as explained above, currently unacceptable in the WTO system. Denying that the WTO, like any adjudicatory body, is limiting rights and extending obligations would be even more problematic in cases dealing with activities of individuals. Lax WTO review tests are therefore rightly too lax to be able to effectively review merger decisions and achieve their unification.

Although WTO law is by no means epiphenomenal, limits do exist, as can be seen both with the measures having equivalent to quantitative restrictions, and with its powers on individuals. The WTO would have an independent impact on international antitrust, as will be further shown below, but could not at the same time effectively deal with different (doctrinal) approaches, or effectively review discriminatory decisions. Differences in national merger enforcement portrayed by the two big cases are therefore here to stay.

\section{THE ClaSh BETWEEN ANTITRUST AND INTERNATIONAL TRADE}

Should the WTO be given a limited role dealing only with rights and obligations of states in antitrust adjudication? Is the opposition of U.S. lawyers and regulators ${ }^{309}$ and some developing countries, ${ }^{310}$ who argue that WTO decision-making would compromise antitrust with trade issues warranted?

Tarullo, for example, argues that the market-access orientation of WTO panels might lead them to rule that the conduct in question was in violation of the law, regardless of whether this conduct was efficient or defensible from the perspective of antitrust law. ${ }^{311}$ Tarullo warns that "even where the norms can be reconciled in principle, the practical implementation of an arrangement in a particular institutional context may tend to favor one norm over another.",312

The experience of E.U. law confirms American doubts. The jurisprudence of the ECJ is very instructive, as it deals with the tension between access to the market and competition concerns. Agreements, containing provisions which have the effect of partitioning the market along national lines,

309. See Tarullo, supra note 5, at 493; Fox, supra note 209, at 248 ("[A] multilateral or plurilateral initiative would lead to corruption of the antitrust principles (which aid consumers) by trade principles (which protect competitors)."); Fox, Competition Law Reprint, supra note 207 , at 1133 .

310. See, e.g., Daniel Pruzin, Trade Officials Assess Winners, Losers In Aftermath of Doha Ministerial Meeting, 18 INT'L TRADE REP. (BNA) 1856 (Nov. 22, 2001) (noting that in the Doha round, India raised a concern that the benefits of International antitrust regulation will go to foreign corporations, and that the WTO will listen to developed countries' market access concern and not to the benefits of consumers in the developing countries).

311. Tarullo, supra note 5, at 493.

312. Id. at 487 . Domination of one policy has also mirrored in disagreements between national constitutional courts, or courts of equivalent rank, and the ECJ, where the relationship as far as European Community Law is concerned eventually became vertical, and could not remain horizontal if the goal of a common market - free trade - was to be achieved. See generally CRAIG \& DE BÚRCA, supra note 256, at 275-316. 
are likely to be treated harshly by the ECJ. ${ }^{313}$ Indeed, the ECJ argued that a violation of Article 81 of the Treaty, prohibiting anticompetitive practices "which may affect trade between Member States," exists even if an anticompetitive agreement is confined to a single member state, where the activity in question reinforces compartmentalization of markets on a national basis. $^{314}$ In a clash between market access and efficiency, the ECJ has shown its preference for the former. ${ }^{315}$

Similarly, the primary goal of the WTO is free trade, thus the prohibition of barriers to trade. ${ }^{316}$ General U.S. opposition to the WTO as the forum for antitrust disputes ${ }^{317}$ therefore seems to be warranted. Although at first glance the goals of free trade and antitrust seem to be the same (free trade in the broadest sense), ${ }^{318}$ it is obvious at the implementation level that they may actually conflict.

Creating a completely new World Competition Forum ${ }^{319}$ may avoid the problem of decision-making in which market access would have priority over antitrust issues. But can decision-making on antitrust and market access really be completely separated? The breadth and range of the ideology of free trade can be seen in the jurisprudence of the ECJ, as well as in the whole array of functions the European Union performs, instead of or alongside member states. "Trade policy increasingly implicates the clash, or potential clash, of liberal commercial values with regulatory or other non-trade aims." ${ }^{321}$ Antitrust may thus be just another issue in line with others that unsuccessfully clashed

313. CRAIG \& DE BÚRCA, supra note 256 , at 957.

314. VALENTINE KORAH, AN INTRODUCTORY GUIDE TO EC COMPETITION LAW AND PRACTICE 54-55 (2000). See Case 8/72, Vereeniging van Cementhandelaren v. Commission, 1972 E.C.R. 977, paras. 29-30.

315. See Case 58/64, Consten and Grundig v. Commission, 1966 E.C.R. 299. In this case, the ECJ decided that since the exclusive distribution agreement was aimed at isolating the French market for Grundig products and artificially maintained separate markets within the Community, for products of a very-well known brand, it distorted competition within the Common Market. De Búrca's critique is practically the same as Tarullo's critique of the WTO dealing with competition policy. She argues that if one were engaging in a pure economic analysis, which involved trade-offs between the pro and anti competitive effects of the agreement, then even absolute territorial protection might be warranted; the protection might be necessary to enable the manufacturer to penetrate a new market, and any reduction in intrabrand competition would be more than offset by inter-brand competition. See CRAIG \& DE BúRCA, supra note 256, at 957 . Thus, opening markets may sometimes not be the most efficient option.

316. See Tarullo, supra note 5, at 479.

317. See, e.g., Klein, supra note 19.

318. See JACKSON ET AL., supra note 148 , at 1110.

319. Fox, supra note 5 , at 670-78.

320. Though the level of integration between the two organizations differs significantly, this does not mean that WTO law touches many less areas of social reality in quantitative terms. This can be seen from the exceptions to free trade of goods in Article XX of the General Agreement on Tariffs and Trade. See GATT, supra note 211, at art. XX; EC TREATY art. 30.

321. Tarullo, supra note 5 , at 489. 
with trade in the WTO, such as the environment, ${ }^{322}$ labor standards, ${ }^{323}$ and potentially intellectual property. ${ }^{324}$ Practically any field of social life therefore conflicts, or at least has a potential to conflict, with the ideology of free trade:

Every field of business regulation is a trade issue, and trade is dependent on every other area of business regulation. This fact is analogous to the fact in domestic society that every field of business regulation affects the market and the market is dependent on every area of public policy. ${ }^{325}$

In this respect, it is difficult to clearly separate trade issues on the one hand, and antitrust issues - or any other issue such as the environment or labor- on the other, and thus antitrust issues which are trade issues and those which are not. ${ }^{326}$ In the Shrimp/Turtle case, for example, one could not separate the question of the environment and the question of free trade. ${ }^{327}$

Questions from any field of social reality can be framed in the language of free trade and thus become trade issues. ${ }^{328}$ This is why it should not be surprising that the WTO is deciding on issues such as the environment, human rights, and labor. ${ }^{329}$ Once a decision-making body is confronted with abstract rules and concrete questions, one cannot expect that they will avoid other areas of social reality that conflict with the broad theory of international trade. If the DSB want to solve a dispute without resorting to non-liquet, ${ }^{330}$ they will touch on these issues willy-nilly. The drafters of the GATT obviously anticipated such a development, otherwise there would not be so many exceptions to free

322. U.S. Shrimp Products, supra note 282.

323. For the relationship between trade and labor, and consequently between ILO and WTO, see Andrew T. Guzman, Trade, Labor, Legitimacy, 91 CAL L. REV. 885 (2003).

324. For the clash of intellectual property rights with the principles of free market, see, e.g., CRAIG \& DE BÚRCA, supra note 256, at 1088-89.

325. Joel P. Trachtman, The International Economic Law Revolution, 17 U. PA. J. INT'L ECON. L. 33, 60 (1996).

326. Cf. Tarullo, supra note 5, at 479 (arguing that "no matter how adroitly the two sets of norms [antitrust and trade] are reconciled in theory, they cannot realistically be expected to remain in happy equipoise in practice").

327. See U.S. Shrimp Products, supra note 282.

328. See Brian Langille, Fair Trade is Free Trade's Destiny, in 2 FAIR TradE AND HARMONIZATION 231 (Jagdish Bhagwati \& Robert E. Hudec eds., 1996); see also Tarullo, supra note 5, at 492-93 (arguing that an argument for market access violation could be framed because of the lack of antitrust enforcement). Similarly, abortion, which one would hold either as a fundamental human right or its violation, was categorized by the ECJ as a service within the meaning of Article 49 of the EC Treaty. See Case 159/90, Society for the Protection of Unborn Children v. Grogan, 62 E.C.R. 849 (1991). Consequently, there is a long line of cases in which there have been overlaps between the ECJ and the European Court of Human Rights ("ECHR"). See CRAIG \& DE BÚRCA, supra note 256, at 365-68.

329. Cf. Tarullo, supra note 5, at 489 ("Even some supporters of the contemporary, legalized system fear that the dispute settlement process is being stretched to its limits.").

330. JACKSON ET AL., supra note 148 , at 300. 
trade. ${ }^{331}$ Adding the fact that at least in hard cases an adjudicatory body will extend obligations and shrink rights, there should be no surprise at the current situation in which the WTO is a decision-maker on nearly every area of social reality.

Despite the fact that these questions often cannot be separated, should an international antitrust organization, an international environmental organization, ${ }^{332}$ or an organization be created for every policy which the populace would like to advance with decision-making powers similar to those of the WTO? Should the same powers be given to existing organizations, such as the International Labor Organization (ILO)?

First, giving the same powers as those held by the WTO to any other organization is not realistic, given the outrage at the WTO's presumably "supranational" decision-making powers ${ }^{333}$ and the simple fact that the overly represented interests ${ }^{334}$ care more about free trade than about the environment, poverty, and other policies per se. Second, even if such a consensus does exist, a settlement of conflicts is unlikely between trade and non-trade issues, should these organizations have the same decision-making powers as the WTO. As has been seen in international merger review, horizontal proliferation of tribunals can be troublesome. Polycentric decision-making on the same issue can create stalemates and disputes, particularly when all voices are heard. ${ }^{335}$

Fox believes that there are antitrust issues, which are trade issues that can thus be dealt with by the WTO. ${ }^{336}$ By incorporating them within the WTO, however, market access would be given priority over other efficiency concerns, as is shown by the jurisprudence of the ECJ. According to Fox, there are other antitrust issues that are not trade issues, which are at the heart of competition law and deserve to be placed on "competition" ground. ${ }^{337}$ Thus, a free-standing World Competition Forum should be created. However, if such a distinction is possible, if there are antitrust issues that are trade issues and others that are not, there is no reason why the non-trade issues could not be incorporated into the WTO. If trade/non-trade separation is possible, the fear that market access concerns would override antitrust concerns would not be justified, as these

331. See GATT, supra note 211, at art. XX; EC TREATY art. 30.

332. See, e.g., JoHN Whalley \& BEN Zissimos, A World ENVIRONMENTAL ORGANIZATION? (2002).

333. See Nader \& Wallach, supra note 305, at 94.

334. See comment, supra note 145.

335. See Tarullo, supra note 5, at 500. Similarly, a concern has been raised about the proliferation of international courts and tribunals in a horizontal legal arrangement addressing the same dispute, without adequate rules for dealing with overlapping jurisdiction. See Kingsbury, supra note 178 , at 683.

336. See Fox, supra note 5, at 671 (arguing that there are three types of market access restraints that should be dealt with in the WTO: (1) exclusions by monopoly or dominant firms; (2) cartels with boycotts; and (3) vertical restraints such as exclusive dealing by the few leading firms in high barrier, concentrated markets - while other antitnust issues should be dealt with in an independent forum).

337. Id. 
issues are not connected. Given the WTO's advantages, which separate it from the faith of the World Intellectual Property Organization (WIPO), ${ }^{338}$ there is no reason why, in line with the "separation" argument, these issues should not be dealt with by the WTO.

Furthermore, a system in which one organization would presumably decide on environmental or antitrust issues and the other on trade concerning the same dispute, should be avoided. If, however, jurisdictional lines are drawn, they will not be able to be drawn on the trade/non-trade separation, as these issues often cannot be separated within a concrete case. As a norm works differently in different institutions and legal systems, ${ }^{339}$ stakes of jurisdictional separation would be high.

Given both the impossibility in the near future of forming other adjudicative organizations in the international arena similar to the WTO, and concerns about separating trade and non-trade issues, other international organizations such as the WIPO, the ILO, and a potential World Competition Forum ${ }^{340}$ could be incorporated into the existing WTO dispute resolution system when particular non-trade issues are in dispute-that is, of course, under the belief that this would produce better results than non-adjudicative resolution of conflicts. At first this could be furthered with an obligatory consultative role, which might leave an open door for a later transformation into the form of a co-decision. ${ }^{341}$ In this way other policies, which until now have constituted relatively silent voices, may be more effectively voiced, avoiding stalemate and duplication.

\section{CONCLUSION}

Disputes are themselves inevitable byproducts of a globalizing economy. Interest-balancing, non-discrimination clauses, fast and flexible cooperation practices, or new and established organizations would solve them, and ideally all nations should adopt antitrust laws, and be able to exercise extraterritorial effect to do away with lurking notions of physical power embodied in the principle of territoriality. It is not important who decides the case, as courts act as a global community where justice and reason reign supreme. It all appears very determinate and "natural." 342

However, law in action and its distributive evaluation show that it is not. Having multiple decision-makers on the horizontal level deciding on the same activity raises the problem of how the "legalization" of international law will cope with a polycentric world. Conflicts arising from extraterritorial effect, out

338. Guzman, supra note 126 , at 19-26.

339. See supra Part II. B.

340. Fox, Competition Law Reprint, supra note 207.

341. The experience of the European Parliament is most instructive in this context. See CRAIG \& DE BúrCA, supra note 256, at 79-80.

342. See Slaughter, A Global Community of Courts, supra note 7, at 210. 
of a mirror image of the principle of territoriality, can to some extent be managed only until this doctrine works in a distributively unjust way, where some interests are voiced and others are not. A "fair" 343 version of extraterritorial effect would produce more disputes than the world community can handle under the current arrangements.

Neglecting the role of power and the role of struggle for power ${ }^{344}$ can thus result in a promotion of power. Power means not only physical and economic power, but also the power of logic, ${ }^{345}$ the power of the established, ${ }^{346}$ and many other types of power, ${ }^{347}$ and most importantly the combination of powers. Rules that are not premised on the power-relations explanation of the world can just as well favor the powerful. Evaluation of the law in action ${ }^{348}$ will tell us which individuals and groups are winning, and which ones losing, in the competition between interests, ${ }^{349}$ and how law-the background rulescontributes to this process. ${ }^{350}$

The power of reason ${ }^{351}$ cannot be overcome, due to both lax standards of international law and the nature of adjudication. Moreover, it is not realistic to crush a national court's authority, its reasoned decision, and the resulting "acquired" rights after a final decision is made at national level. "What is, is right." 352 The world must therefore face up to what has been created-an

343. Dodge, supra note 28 , at 390.

344. See Slaughter, Liberal International Relations Theory and International Economic Law, supra note 7, at 742 ("The Liberal approach analyzes extraterritoriality as a regulatory problem rather than a power problem.").

345. See, e.g., Barry Stroud, Wittgenstein and Logical Necessity, in WITTGENSTEIN's PHILOSOPHICAL INVESTIGATIONS 477-496 (Pitcher ed., 1966). For Hegel's account of absolute reason, see, e.g., 7 FREDERICK COPLESTON S. J., A History OF PHILOSOPHY: 18TH AND 19TH Century German PhiLOSOPHY 190 (Doubleday Dell Publishing 1999) (1963).

346. Roberto M. Unger, Politics: The CEntral TeXts 75 (1997) (waming that an advance toward disentrancement should not be mistaken for a move toward anarchy); $c f$. KENNEDY, supra note 74, at 236 ("According to the legitimation hypothesis, the particular set of hierarchies that constitute our social arrangements look more natural, more necessary, and more just than they 'really' are.").

347. For power as defined by Deutsch, see DEUTSCH, supra note 36. For Unger's account of power, see UNGER, supra note 37. For an account of power as the multiplicity of force relations immanent in the sphere in which they operate and which constitute their own organization, see 1 Michel FoucaulT, THE HistoRy OF SEXUALITY 93 (1978).

348. Holmes, supra note 8.

349. Moravcsik, supra note 32, at 517.

350. See David Kennedy, Background Noise? The Underlying Politics of Global Governance, 21 HARV. INT'L REV. 52, 57 (1999); see also KENNEDY, supra note 74, at 74.

351. See Holmes, supra note 8, at 465-66 ("The language of decision-making is mainly the language of logic .... Behind the logical form lies a judgment as to the relative worth and importance of competing legislative grounds, often an inarticulate and unconscious judgment, it is true, and yet the very root and nerve of the whole proceeding."); NIETZSCHE, supra note 232, at 277-78 (arguing that categories of reason have mistakenly "counted as a priori, as beyond experience, as irrefutable" and that "their utility alone is their 'truth"'). See also supporting authority contained within supra note 345 .

352. Morris R. Cohen, Book Review, 22 CoRnell L.Q. 171, 177 (1936) (reviewing EDWARD S. ROBINSON, LAW AND THE LAWYERS (1935)). 
effective veto right that, when exercised, escalates into a dispute between nations. This veto right is at least as strong as the veto right of the permanent members of the Security Council of the United Nations, ${ }^{353}$ due to economic power and the fact that once a decision has been taken, we have moved into the realm of the power of reason. 
